\title{
Circulating Concentrations of Adipocytokines and Their Receptors in the Isolated Corpus Cavernosum and Femoral Artery from Trained Rats on a High-Fat Diet
}

\author{
Amanda C.S. Sponton ${ }^{\mathrm{a}}$ Fábio H. Silva ${ }^{\mathrm{b}}$ Hygor N. Araujo $^{\mathrm{a}}$ \\ Carmem P. Valgas da Silva ${ }^{c}$ Camila de Moraes ${ }^{d}$ Edson Antunes ${ }^{b}$ \\ Angelina Zanesco ${ }^{e}$ Maria A. Delbin $^{a}$ \\ a Department of Structural and Functional Biology, Institute of Biology, and bepartment of Pharmacology, Faculty \\ of Medical Sciences, University of Campinas (UNICAMP), Campinas, 'Department of Physical Education, Institute of \\ Biosciences, Universidade Estadual Paulista (UNESP), Rio Claro, ${ }^{\mathrm{d}}$ School of Physical Education and Sport of Ribeirão \\ Preto, University of São Paulo (USP), Ribeirão Preto, and ' ${ }^{\mathrm{F}}$ aculty of Medicine, UNICASTELO, Fernandópolis, Brazil
}

\section{Keywords}

Corpus cavernosum - Femoral artery · Aerobic exercise ·

Adipocytokines · High-fat diet · Endothelial dysfunction

\begin{abstract}
Background: The aim of the present study was to evaluate different signaling pathways by which exercise training would interfere in endothelial function in obesity. Therefore, we examined adipocytokine levels and their receptors in the corpus cavernosum and femoral artery from trained rats on a high-fat diet. Methods: Functional experiments were performed in control sedentary and trained rats, and sedentary (h-SD) and trained male Wistar rats on a high-fat diet (h-TR). Nitric oxide (NO) and reactive oxygen species (ROS) were evaluated in vascular tissue. Circulating adipocytokines and their receptors were analyzed. Results: In the h-SD group, the maximal responses to acetylcholine ( $\mathrm{ACh}$ ) were reduced in the femoral artery and corpus cavernosum as well as the electrical field stimulation, accompanied by an increase in circulating insulin, leptin, TNF- $a$, MCP-1, and PAI-1. Downregulation of ObR protein expression in the femoral artery was observed without alterations in AdipoR1 and TNFR1 in both prepara-
\end{abstract}

(C) 2017 S. Karger AG, Basel
E-Mail karger@karger.com www.karger.com/jvr tions. A positive effect was observed in the h-TR group regarding the relaxation response to $\mathrm{ACh}$ and circulating adipocytokines, resulting in increased NO production and reduced ROS generation. Exercise restored the ObR protein expression only in the femoral artery. Conclusion: Aerobic exercise training ameliorated the inflammatory adipocytokines and restored the relaxation responses in the corpus cavernosum and femoral artery in rats on a high-fat diet.

(c) 2017 S. Karger AG, Base

\section{Introduction}

Erectile dysfunction has been recognized as an early signal for cardiovascular diseases because the penile vascular bed is a sensitive indicator of systemic vascular diseases [1]. Obesity is considered a significant independent risk factor for erectile dysfunction, and its prevalence is projected to increase beyond the obesity rates [2]. Previous studies have shown that lifestyle changes improve erectile dysfunction in obese men [3], and our laboratory has systematically shown that exercise training ameliorates the relaxation response of the rat corpus caverno- 
sum in hypertensive as well as diabetic animals $[4,5]$. However, few studies have examined the effects of dietinduced obesity on erectile function in rats, and potential mechanisms were not evaluated $[6,7]$. Thus, the assessment of corpus cavernosum function would be useful to prevent or detect those at risk of cardiovascular events in obesity.

Evidence has shown that an association between obesity, atherosclerosis, and endothelial dysfunction is the primary cause of peripheral artery disease affecting lower-extremity arteries such as the iliac, popliteal, and femoral arteries $[8,9]$. A higher risk of morbidity and fatal cardiovascular events in patients with peripheral arterial disease has also been demonstrated $[10,11]$, and this disorder has not been as extensively investigated as other cardiovascular diseases such as coronary artery disease. Physical exercise has been demonstrated to be an important nonpharmacological tool to improve blood flow and to reduce lower limb pain in patients with peripheral artery disease [12-14]. In addition, studies associating vascular responses and obesity using the isolated femoral artery in exercise protocol models are scarce.

Endothelial dysfunction as a consequence of metabolic and inflammatory disorders plays an important role in the initiation of vascular complications in obesity [15] and is the hallmark of obesity associated with erectile dysfunction and coronary and peripheral artery disease [16, 17]. Considering the interaction between proinflammatory mediators and vascular diseases in obesity, many studies investigated the involvement of circulating adipocytokine concentrations and endothelial dysfunction [18-21]. Interestingly, adipocytokine receptors such as the long and short forms of the leptin receptor (ObR) $[22,23]$ and tumor necrosis factor (TNF)- $\alpha$ receptor 1 (TNFR1) have been poorly investigated, although some studies have demonstrated the involvement of these receptors in vascular regulation [24-26]. Therefore, the hypothesis of this study is to test whether exercise training may cause alterations in adipocytokines and their receptors using two different vascular tissue types. The relevance of the present approach is to evaluate different signaling pathways by which exercise training would interfere in endothelial function in obesity. Thus, the aim of the present study was to examine the circulating concentrations of adipocytokines (adiponectin, leptin, and TNF- $\alpha$ ) and their receptors in the isolated corpus cavernosum and superficial femoral artery from trained rats on a high-fat diet. To further investigate the potential mechanisms, we also measured the tissue redox state and nitric oxide $(\mathrm{NO})$ production.

\section{Methods}

\section{Animals}

Male Wistar rats (weighing 290-320 g) were obtained from the Animal Care Facility of UNICAMP and were maintained in a room at $22-24^{\circ} \mathrm{C}$ with a normal 12 -h light/dark cycle. Food and water were provided ad libitum to all animals. The animals were housed in groups of 2 or 3 per cage and were divided into 4 experimental groups: sedentary (c-SD) and trained control rats (cTR), and sedentary (h-SD) and trained rats on a high-fat diet (hTR). For 16 weeks, animals in the c-SD and c-TR groups were fed standard chow (energy content derived from $76 \%$ carbohydrates, $14 \%$ protein, and $10 \%$ lipids), whereas animals in the $\mathrm{h}-\mathrm{SD}$ and $\mathrm{h}$-TR groups were fed a high-fat diet (energy content derived from $56 \%$ carbohydrates, $18 \%$ proteins, and $26 \%$ lipids, according to a previous study) [27]. After 8 weeks of study, animals in the c-TR and h-TR groups initiated aerobic exercise training, which was maintained until the end of the protocol.

\section{Aerobic Exercise Training}

Animals were trained on a treadmill designed for small animals with individual lanes (Gesan, Brazil). One week before starting the training program, the animals were adapted to the treadmill in an attempt to minimize potential stress; only adapted animals were used in the present study. At the end of the adaptation period, the intensity of the training was determined by acute incremental exercise testing on the treadmill during which the intensity of the exercise was increased by $5 \mathrm{~m} / \mathrm{min}(5-30 \mathrm{~m} / \mathrm{min})$ every $3 \mathrm{~min}$ at a $0 \%$ grade until exhaustion (defined as an inability to maintain running speed). The maximal speed was used to calculate moderate intensity as a percentage (50-60\%) of maximal speed.

The training program consisted of sessions of $60 \mathrm{~min} /$ day, 5 days/ week, at a $0 \%$ grade and at $50-60 \%$ of the maximal speed for 8 weeks. In the first week of the training program, the duration and speed started at $10 \mathrm{~m} / \mathrm{min}$ for $30 \mathrm{~min}$ and progressively increased to $15 \mathrm{~m} /$ min for $60 \mathrm{~min}$. From weeks 2 to 8, the training program consisted of $10 \mathrm{~min}$ at $40 \%$ of maximal speed, $40 \mathrm{~min}$ at $50-60 \%$ of maximal speed, and $10 \mathrm{~min}$ at $40 \%$ of maximal speed (total of $60 \mathrm{~min} /$ day). All animals were trained in the early morning between 6:00 and 8:00 a.m.

Sedentary and trained rats were submitted again to acute incremental exercise testing on the treadmill during the last week of the study to evaluate the effectiveness of the training program. This test provided the total distance, total time, and maximal speed for each animal.

\section{Blood Samples and Tissue Collection}

At $48 \mathrm{~h}$ after the last exercise training session and after $12 \mathrm{~h}$ of fasting, blood samples were collected from the tail vein, and blood glucose was measured using standard test strips (Accu-Chek Advantage; Roche Diagnostics, USA). Immediately after blood collection, the animals were anesthetized ( $40 \mathrm{mg} / \mathrm{kg}$ sodium thiopental, i.p.), and arterial blood samples were collected from the abdominal aorta in different tubes and centrifuged $(8,000 \mathrm{~g}$ for $15 \mathrm{~min})$. The serum and plasma supernatants were stored at $-80^{\circ} \mathrm{C}$ for biochemical analysis. The animals were euthanized, and the epididymal fat pad was collected and weighed. The superficial femoral artery and the corpus cavernosum were carefully isolated and placed in freshly prepared ice-cold Krebs solution containing (in $\mathrm{mM}$ ): $118 \mathrm{NaCl}$, $25 \mathrm{NaHCO}_{3}, 5.6$ glucose, $4.7 \mathrm{KCl}, 1.2 \mathrm{KH}_{2} \mathrm{PO}_{4}, 1.1 \mathrm{MgSO}_{4} \times 7 \mathrm{H}_{2} \mathrm{O}$, and $2.5 \mathrm{CaCl}_{2} \times 2 \mathrm{H}_{2} \mathrm{O}$. 
Biochemical Analyses

Total cholesterol and triglyceride levels were measured in serum samples using standard commercial kits (Roche Diagnostics). Insulin concentrations were also measured in serum samples using a commercially available ELISA kit (Alpco, USA). The homeostasis model assessment of insulin resistance (HOMA-IR) was calculated according to a method described previously [28]. Plasma levels of adiponectin, leptin, TNF- $\alpha$, monocyte chemoattractant protein-1 (MCP-1), and plasminogen activator inhibitor-1 (PAI-1) were determined using the Luminex 200 kit (Millipore-Luminex, USA), according to the manufacturer's instructions.

\section{Functional Studies in the Femoral Artery}

The superficial femoral artery was cleaned of all adherent tissue and cut into rings of $2 \mathrm{~mm}$; 2 wires ( $40 \mathrm{~mm}$ in diameter) were introduced through the lumen of the segments and mounted in a small-vessel myograph chamber (model 610M; Danish Myo Technology, Denmark) with $5 \mathrm{~mL}$ Krebs solution at $37^{\circ} \mathrm{C}$, pH 7.4, and continuously gassed with $95 \% \mathrm{O}_{2}$ and $5 \% \mathrm{CO}_{2}$ under a resting tension of $0 \mathrm{mN}$. After $15 \mathrm{~min}$ of equilibration, the rings were stretched to their optimal lumen diameter based on the internal circumference, wall length, and wall tension using specific software for normalization (LabChart Pro-DMT Normalization Module; ADInstruments, Australia). Data acquisition was performed using PowerLab 8/30 (LabChart, version 7.0; AD Instruments). The normalization was performed by distending the vessel stepwise and measuring sets of micrometer force readings [29, 30].

After 45 min of stabilization, the femoral rings were contracted with $80 \mathrm{~mm} \mathrm{KCl}$ and washed with Krebs buffer to verify tissue viability. Later, the rings were precontracted with a thromboxane analog, 9,11-dideoxy-11a,9 $\alpha$-epoxymethanoprostaglandin $F_{2 a}$ (U46619), at a concentration necessary to produce $50-80 \%$ of the maximal response of $80 \mathrm{mM} \mathrm{KCl}$, and cumulative concentrationresponse curves to the relaxation agents acetylcholine (ACh, $1 \mathrm{nM}$ $100 \mu \mathrm{M}$ ) and sodium nitroprusside (SNP, $100 \mathrm{pM}-1 \mathrm{mM}$ ) were obtained. Relaxation responses were plotted as a percentage of the contraction induced by U46619. Cumulative concentration-response curves were also obtained for the contractile agents $a_{1}$ adrenergic receptor agonist phenylephrine (PHE, $10 \mathrm{nM}$ to 100 $\mu \mathrm{M})$, or the thromboxane analog U46619 (1 nM to $10 \mu \mathrm{M})$. Contractile responses were plotted according to the force and length from each ring as millinewtons per millimeter.

All concentration-response data were fit to a logistic function, and nonlinear regression analysis was used to determine the parameters $\mathrm{E}_{\mathrm{MAX}}$ (maximum response) and $\log \mathrm{EC}_{50}$ (logarithm of the concentration of an agonist that produces a half-maximal response) using GraphPad Prism version 5.0 software (GraphPad, USA) with the constraint that $\Phi=0$. The responses for each agonist are shown as the mean \pm SEM of potency $\left(\mathrm{pEC}_{50}\right)$ and $\mathrm{E}_{\mathrm{MAX}}$.

\section{Functional Studies in the Corpus Cavernosum}

Strips of the rat corpus cavernosum were vertically suspended between two metal hooks in a $10-\mathrm{mL}$ organ system containing Krebs solution at $37^{\circ} \mathrm{C}, \mathrm{pH} 7.4$, and continuously gassed with $95 \%$ $\mathrm{O}_{2}$ and $5 \% \mathrm{CO}_{2}$. One hook was connected to a force transducer, and the other acted as a fixed attachment point. Tissues were allowed to equilibrate for 60 min under a resting tension of $5 \mathrm{mN}$. Isometric force was recorded using a PowerLab 400 data acquisition system (Software LabChart, version 7.0; AD Instruments).

Aerobic Exercise Training and Vascular

Function in High-Fat-Fed Rats
Electrical field stimulation (EFS) was applied in strips placed between two platinum ring electrodes connected to a Grass S88 stimulator (Astro-Med, USA). Contractile and relaxation responses to EFS were conducted at $50 \mathrm{~V}$ with a 1-ms pulse width and trains of stimuli lasting $10 \mathrm{~s}$ at varying frequencies $(4,8,16$, and $32 \mathrm{~Hz})$ [31]. To verify the EFS-induced relaxation, tissues were pretreated with guanethidine $(30 \mu \mathrm{M})$ and atropine $(1 \mu \mathrm{M})$ to deplete the catecholamine stores of adrenergic fibers and to block muscarinic receptors, respectively. After $30 \mathrm{~min}$, the tissues were precontracted with PHE (10 $\mu \mathrm{M})$, and EFS was performed to verify the relaxation response. In another set of experiments, contractile responses to EFS were evaluated by obtaining frequency-response curves. In all experiments, preparations were allowed to recover completely from each response before the next stimulus. Each strip was used to obtain a single EFS curve. Frequency-response relationships were investigated at supramaximal voltage in all preparations stimulated electrically.

Cavernosal strips were precontracted with PHE $(10 \mu \mathrm{M})$ and cumulative concentration-response curves for ACh ( $1 \mathrm{nM}$ to $1 \mathrm{mM}$ ) and SNP (10 nM to $10 \mathrm{mM}$ ) were obtained. Relaxation responses were plotted as a percentage of the contraction induced by PHE. Cumulative concentration-response curves were also obtained for PHE (10 nM to $100 \mu \mathrm{M})$. Contractile responses were plotted according to each strip in millinewtons.

\section{Western Blot Analysis}

The expression of proteins was determined by Western blot in superficial femoral artery and corpus cavernosum tissue lysates. Frozen segments were homogenized in a RIPA lysing buffer (Merck Millipore, USA) with $1 \mathrm{mM} \mathrm{Na}_{3} \mathrm{VO}_{4}, 1 \mathrm{~mm}$ phenylmethylsulfonyl fluoride, and protease inhibitor cocktail $(2 \mu \mathrm{L} / \mathrm{mL}$ ) (Sigma-Aldrich, USA). The tissue lysate was centrifuged $\left(1,500 \mathrm{~g}\right.$ for $30 \mathrm{~min}$ at $\left.4^{\circ} \mathrm{C}\right)$, and the supernatant was collected. The protein concentration was determined using the BCA protein assay kit (Pierce, USA).

Proteins from the homogenized femoral artery $(50 \mu \mathrm{g})$ and corpus cavernosum $(100 \mu \mathrm{g})$ were electrophoretically separated by SDS-PAGE (femoral artery: 4-15\% Mini-Protean TGX, and corpus cavernosum: 7.5 or 12\% Mini-Protean II, Eletrophoresis Cell; Bio-Rad, USA). Membranes were incubated overnight with the following primary antibodies: mouse monoclonal anti-endothelial NO synthase (eNOS, 1:1,000; BD Transduction, USA), rabbit polyclonal anti-neuronal NO synthase (nNOS, 1:1,000; Transduction Laboratories, San Jose, CA, USA; only in the corpus cavernosum), anti-adiponectin receptor R1 (AdipoR1, 1:1,000; Novus Biologicals, USA), short and long isoforms of anti-leptin receptor (ObR, 1:1,000; Novus Biologicals), anti-TNF- $\alpha$ receptor 1 (TNFR1, 1:1,000; Santa Cruz Biotechnology, USA), anti-Cu/Zn superoxide dismutase (Cu/Zn-SOD, 1:1,000; Sigma-Aldrich), anti-extracellular superoxide dismutase (Ec-SOD, 1:1,000; Enzo Life Sciences, USA), and anti-manganese superoxide dismutase (Mn-SOD, 1:1,000; Axxora LLC, USA). After being washed, membranes were incubated with a secondary peroxidase-conjugated IgG antibody according to each primary antibody used.

Western blotting substrate (Pierce ECL; Thermo Scientific, USA) was used for chemiluminescent detection of protein expression using Image Quant LAS 4000 (GE Healthcare, USA) hardware and software, according to the manufacturer's instructions. The intensity of the blots was quantified using ImageJ 1.46p software (National Institutes of Health, USA). The same membrane was used to determine $\alpha$ - or $\beta$-actin protein expression as an internal control using a mouse monoclonal anti- $\alpha$-actin (1:5,000; Abcam, 
Table 1. Incremental exercise test performed before (BEFORE) and at the end (FINAL) of the exercise training from sedentary (c-SD) and trained control rats (c-TR), and sedentary (h-SD) and trained rats on a high-fat diet (h-TR)

\begin{tabular}{|c|c|c|c|c|c|c|c|c|}
\hline & \multicolumn{4}{|l|}{ BEFORE } & \multicolumn{4}{|l|}{ FINAL } \\
\hline & c-SD (13) & $\begin{array}{l}\text { c-TR } \\
(10)\end{array}$ & $\begin{array}{l}\text { h-SD } \\
(12)\end{array}$ & $\begin{array}{l}\text { h-TR } \\
\text { (13) }\end{array}$ & $\begin{array}{l}\text { c-SD } \\
(13)\end{array}$ & $\begin{array}{l}\text { c-TR } \\
(10)\end{array}$ & $\begin{array}{l}\text { h-SD } \\
(12)\end{array}$ & $\begin{array}{l}\text { h-TR } \\
(13)\end{array}$ \\
\hline \multirow{3}{*}{$\begin{array}{l}\text { Time, min } \\
\text { Distance, } \mathrm{m} \\
\text { Max speed, } \\
\mathrm{m} / \mathrm{min}\end{array}$} & $14 \pm 0.8$ & $14 \pm 0.7$ & $14 \pm 0.7$ & $15 \pm 0.6$ & $15 \pm 0.4$ & $24 \pm 0.9^{*}$ & $13 \pm 0.5$ & $22 \pm 0.6^{+, \#}$ \\
\hline & $182 \pm 20$ & $173 \pm 15$ & $178 \pm 15$ & $192 \pm 13$ & $190 \pm 10$ & $500 \pm 32^{*}$ & $150 \pm 11$ & $400 \pm 22^{+, \#}$ \\
\hline & $23 \pm 1.2$ & $23 \pm 1.2$ & $22 \pm 1.2$ & $24 \pm 0.6$ & $24 \pm 0.6$ & $42 \pm 1.2^{*}$ & $18 \pm 0.6$ & $36 \pm 1.2^{+, \#}$ \\
\hline
\end{tabular}

Data are means \pm SEM. The number of animals per group is indicated in parentheses. Two-way ANOVA: ${ }^{*} p<0.05$ vs. c-SD; ${ }^{+} p<0.05$ vs. h-SD; ${ }^{\#} p<0.05$ vs. c-TR.

USA) and anti- $\beta$-actin (1:1,000; Santa Cruz Biotechnology, USA), and its content was used to normalize protein expression in each sample. The results from the $\mathrm{c}-\mathrm{TR}, \mathrm{h}-\mathrm{SD}$, and $\mathrm{h}-\mathrm{TR}$ groups are presented relative to those of the $\mathrm{c}-\mathrm{SD}$ group $(\mathrm{c}-\mathrm{SD}=1)$.

\section{NO in Tissue}

NO production was evaluated using the NO-sensitive fluorescent dye 4,5-diaminofluorescein diacetate (DAF-2, Sigma-Aldrich) as previously described [30]. Slices of the superficial femoral artery and corpus cavernosum were equilibrated for $10 \mathrm{~min}$ in phosphate buffer $(0.1 \mathrm{M}, \mathrm{pH} 7.4)$ containing $\mathrm{CaCl}_{2}(0.45 \mathrm{~mm})$. Fresh buffer containing DAF-2 $(8 \mu \mathrm{M})$ was topically applied to each tissue section, and the slices were incubated in a light-protected humidified chamber at $37^{\circ} \mathrm{C}$. After 25 min of incubation, some sections of each tissue were stimulated without (basal) or with ACh ( $30 \mu \mathrm{M}$ for the femoral artery and $100 \mu \mathrm{M}$ for the corpus cavernosum) for $15 \mathrm{~min}$.

Digital images were obtained with an optical microscope (Eclipse 80i; Nikon, Japan) equipped with fluorescein filter and camera (DS-U3; Nikon, Japan) using a $\times 20$ (femoral artery) or $\times 10$ (corpus cavernosum) objective. The images were analyzed using the ImageJ $1.46 \mathrm{p}$ software (National Institutes of Health) by the integrative density of the fluorescence observed in the tissue in relation to the background staining in sections with and without ACh stimulation. The results are expressed as the difference in ACh stimulation and basal integrative density. The results from the c-TR, h-SD, and h-TR groups are presented relative to those of the $\mathrm{c}-\mathrm{SD}$ group $(\mathrm{c}-\mathrm{SD}=1)$.

\section{Reactive Oxygen Species in Tissue}

The oxidative fluorescent dye hydroethidine (Invitrogen, USA) was used to evaluate in situ generation or reactive oxygen species (ROS), as previously described [32]. Superficial femoral artery and corpus cavernosum slides were equilibrated for $10 \mathrm{~min}$ in Hanks solution (in mM: $1.6 \mathrm{CaCl}_{2}, 1.0 \mathrm{MgSO}_{4}, 145.0 \mathrm{NaCl}, 5.0 \mathrm{KCl}, 0.5$ $\mathrm{NaH}_{2} \mathrm{PO}_{4}, 10.0$ dextrose, and 10.0 HEPES; $\mathrm{pH} 7.4$ ) at $37^{\circ} \mathrm{C}$. Fresh Hanks solution containing hydroethidine $(2 \mu \mathrm{M})$ was topically applied to each tissue section, and the slices were incubated in a lightprotected humidified chamber at $37^{\circ} \mathrm{C}$ for $30 \mathrm{~min}$.
Negative control sections received the same volume of Hanks solution but without hydroethidine. Images were obtained with an optical microscope (Eclipse 80i; Nikon) equipped with filter to rhodamine and a camera (DS-U3, Nikon) using a $\times 20$ (femoral artery) or $\times 10$ (corpus cavernosum) objective. The number of ethidium bromide-positive nuclei was automatically counted using ImageJ software and expressed as labeled per square millimeter. The results from the c-TR, h-SD, and h-TR groups are presented relative to those of the $\mathrm{c}-\mathrm{SD}$ group $(\mathrm{c}-\mathrm{SD}=1)$.

\section{Drugs}

ACh chloride, SNP dihydrate, PHE hydrochloride, the thromboxane analog 9,11-dideoxy-11a,9a-epoxymethanoprostaglandin $\mathrm{F}_{2 \alpha}$ (U46619), and DAF-2 were purchased from Sigma-Aldrich. Hydroethidine was purchased from Invitrogen.

\section{Statistical Analysis}

Data are presented as the mean \pm SEM of $n$ experiments. Twoway ANOVA followed by Bonferroni post hoc test was performed using Instat Software (GraphPad Prism). Values of $p<0.05$ were considered statistically significant.

\section{Results}

\section{Incremental Exercise Test}

All groups had similar responses to the acute incremental exercise test before starting the exercise training (Table 1). After the exercise training, we verified an improvement in physical performance in the incremental exercise test evaluated by total time (min, approximately $70 \%$ ), total distance (meters, approximately 160\%), and maximal speed ( $\mathrm{m} / \mathrm{min}$, approximately $80 \%)$ in the c-TR and h-TR groups when compared with the c-SD and h-SD groups, respectively (Table 1 ). The h-TR group presented a decrease in exercise performance in all 3 param- 
Table 2. Body weight, epididymal fat pad, and metabolic biomarkers in rats from sedentary (c-SD) and trained control rats (c-TR), and sedentary (h-SD) and trained rats on a high-fat diet (h-TR)

\begin{tabular}{lcccc}
\hline & c-SD $(6-12)$ & c-TR $(6-10)$ & h-SD $(6-12)$ & h-TR $(6-12)$ \\
\hline Initial body weight, g & $298 \pm 5$ & $305 \pm 8$ & $295 \pm 6$ & $307 \pm 5$ \\
Final body weight, g & $547 \pm 12$ & $452 \pm 13^{* * *}$ & $652 \pm 16^{* * *}$ & $549 \pm 11^{+++, \# \#}$ \\
Epididymal fat, g & $8 \pm 0.6$ & $5 \pm 0.4^{*}$ & $23 \pm 2^{* * *}$ & $14 \pm 1^{+++}$\#\#\# \\
Total cholesterol, mg/dL & $76 \pm 12$ & $77 \pm 8$ & $82 \pm 9$ & $72 \pm 11$ \\
Triglycerides, mg/dL & $104 \pm 9$ & $60 \pm 8^{*}$ & $233 \pm 11^{* * *}$ & $96 \pm 10^{+++}$ \\
Blood glucose, mg/dL & $92 \pm 2$ & $81 \pm 3^{*}$ & $100 \pm 3$ & $88 \pm 3^{+}$ \\
Insulin, ng/mL & $3 \pm 0.6$ & $3 \pm 0.6$ & $6 \pm 0.7^{* *}$ & $3 \pm 0.5^{++}$ \\
HOMA-IR & $0.57 \pm 0.08$ & $0.45 \pm 0.07$ & $1.43 \pm 0.08^{* * *}$ & $0.61 \pm 0.07^{+++}$ \\
\hline
\end{tabular}

Data are means \pm SEM. The number of animals per group is indicated in parentheses. Two-way ANOVA: ${ }^{*} p<0.05,{ }^{* *} p<0.01,{ }^{* * *} p<0.001$ vs. $\mathrm{c}-\mathrm{SD} ;{ }^{+} p<0.05,{ }^{++} p<0.01,{ }^{+++} \mathrm{p}<0.001 \mathrm{vs.} \mathrm{h-SD;}{ }^{\# \# \#} p<0.001$ vs. c-TR.

eters analyzed (10, 20, and 15\%, respectively) compared with the c-TR group (Table 1).

\section{Body Weight, Epididymal Fat Pad, and Metabolic Biomarkers}

Initial body weights were similar in all groups (Table 2). After the protocol, exercise training in healthy animals (c-TR) decreased body weight (18\%), epididymal fat pad (45\%), and levels of metabolic biomarkers, including blood glucose (12\%) and triglycerides (43\%), compared with the c-SD group (Table 2). In the h-SD group, we observed a significant increase in body weight (19\%), epididymal fat pad (174\%), triglycerides (124\%), and insulin $(88 \%)$ levels, resulting in an alteration in the HOMAIR index compared with the c-SD group (Table 2). Exercise training was effective in preventing all these alterations in the h-TR group compared with the h-SD group.

\section{Relaxation Responses}

Femoral Artery

The diameter of the superficial femoral artery did not differ in any group (c-SD: $427 \pm 21 \mu \mathrm{m}$; c-TR: $419 \pm 11$ $\mu \mathrm{m}$; h-SD: $422 \pm 13 \mu \mathrm{m}$; and h-TR: $410 \pm 5 \mu \mathrm{m})$. ACh and SNP (data not shown) produced concentration-dependent relaxation in isolated femoral rings. Neither the ACh nor the SNP (data not shown) relaxation responses were altered by exercise training in healthy animals in the c-TR group compared with the c-SD group (Fig. 1a). The $\mathrm{E}_{\mathrm{MAX}}$ values for the response to ACh were decreased in the h-SD group compared with the c-SD group (Fig. 1a). No changes were observed in $\mathrm{pEC}_{50}$ values (Table 3 ). Exercise training (h-TR) fully restored the reduction in the $\mathrm{E}_{\mathrm{MAX}}$ compared with h-SD (Fig. 1a). Regarding the concentra-

Aerobic Exercise Training and Vascular

Function in High-Fat-Fed Rats
Table 3. Potency values ( $\mathrm{pEC}_{50}$ ) obtained from concentration-response curves to acetylcholine (ACh), phenylephrine (PHE), and the thromboxane analog U46619 in the rat femoral artery and corpus cavernosum of sedentary (c-SD) and trained control rats (c-TR), and sedentary (h-SD) and trained rats on a high-fat diet (h-TR)

\begin{tabular}{|c|c|c|c|c|}
\hline & \multicolumn{4}{|l|}{$\mathrm{pEC}_{50}$} \\
\hline & $\mathrm{c}-\mathrm{SD}(4-12)$ & c-TR $(4-8)$ & h-SD $(5-10)$ & h-TR (4-9) \\
\hline \multicolumn{5}{|c|}{ Femoral artery } \\
\hline $\mathrm{ACh}$ & $6.83 \pm 0.10$ & $6.63 \pm 0.08$ & $6.55 \pm 0.05$ & $6.50 \pm 0.06$ \\
\hline PHE & $5.41 \pm 0.07$ & $5.53 \pm 0.08$ & $5.52 \pm 0.07$ & $5.49 \pm 0.07$ \\
\hline U46619 & $7.40 \pm 0.12$ & $7.31 \pm 0.15$ & $7.33 \pm 0.11$ & $7.31 \pm 0.08$ \\
\hline \multicolumn{5}{|c|}{ Corpus cavernosum } \\
\hline $\mathrm{ACh}$ & $4.42 \pm 0.11$ & $4.23 \pm 0.08$ & $4.74 \pm 0.09$ & $4.61 \pm 0.10$ \\
\hline PHE & $5.52 \pm 0.02$ & $5.76 \pm 0.06$ & $5.68 \pm 0.06$ & $5.62 \pm 0.05$ \\
\hline
\end{tabular}

Potency is represented as - log of molar concentration to produce $50 \%$ of the maximal responses. Means \pm SEM. The number of animals per group is indicated in parentheses.

tion-response curves for SNP, no alterations were observed in either the $\mathrm{E}_{\mathrm{MAX}}$ or $\mathrm{pEC}_{50}$ values in any group (data not shown).

\section{Corpus Cavernosum}

ACh and SNP (data not shown) produced concentration-dependent relaxation in cavernosal strips. Neither the ACh nor the SNP (data not shown) relaxation responses were altered by exercise training in healthy animals in the c-TR group compared with the c-SD group (Fig. 1b). Similarly, the $\mathrm{E}_{\mathrm{MAX}}$ values for the response to ACh were decreased in the h-SD group compared with 

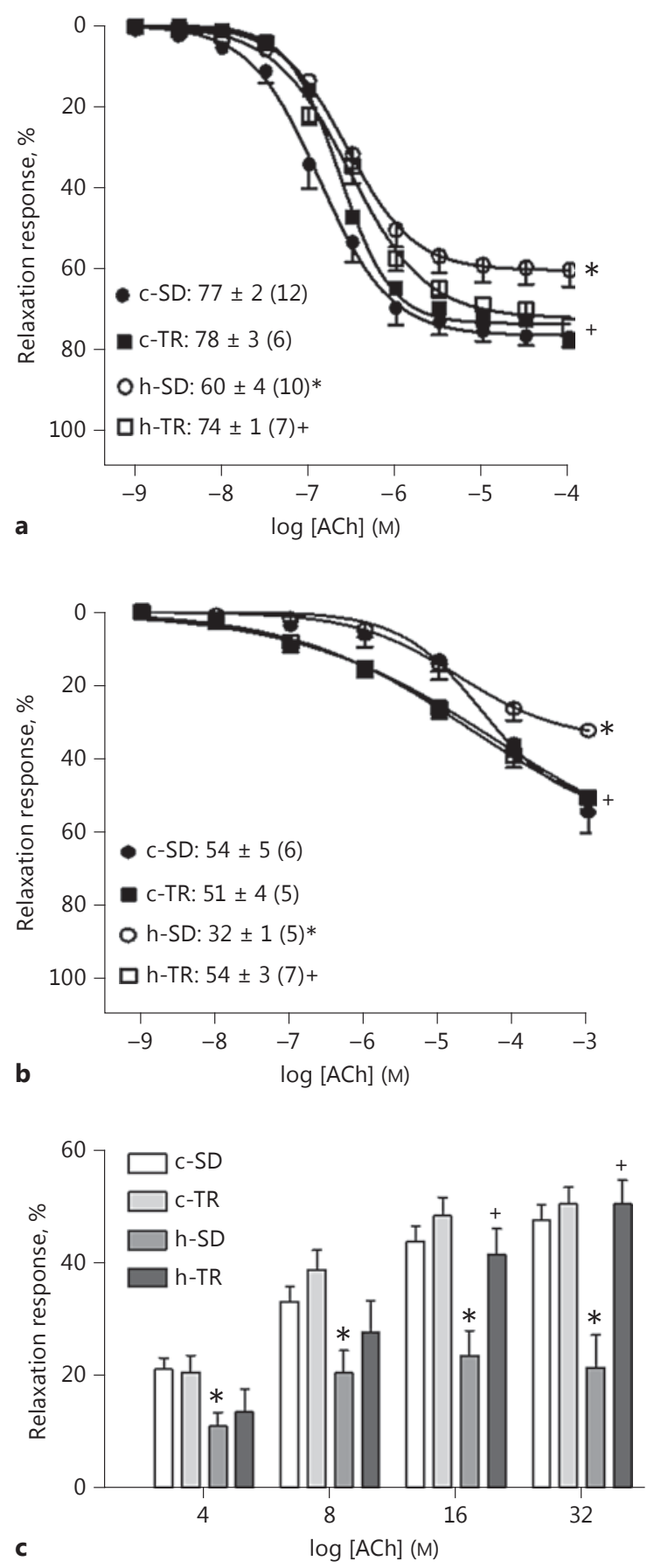

Fig. 1. a, b Concentration-response curves to acetylcholine (ACh) in the femoral artery (a) and corpus cavernosum (b) of sedentary (c-SD) and trained control rats (c-TR), and sedentary (h-SD) and trained rats on a high-fat diet (h-TR). c Corpus cavernosum relaxations to electrical field stimulation (EFS: 4-32 Hz). Maximal response values and means \pm SEM are shown. Numbers of animals are shown in parentheses. Two-way ANOVA: ${ }^{*} p<0.05$ vs. c-SD; ${ }^{+} p<0.05$ vs. h-SD. a Precontracted with U46619. b, c Precontracted with phenylephrine. the c-SD group (Fig. 1b). No changes were observed in the $\mathrm{pEC}_{50}$ values (Table 3 ). Exercise training fully restored the reduction in the $\mathrm{E}_{\mathrm{MAX}}$ in the h-TR group compared with the h-SD (Fig. 1b). EFS-induced frequencydependent relaxations were markedly decreased in the $\mathrm{h}$-SD group compared with the c-SD group at all frequencies studied. Exercise training restored the EFS-induced relaxation response at frequencies of 16 and $32 \mathrm{~Hz}$ in the h-TR group compared with the h-SD group (Fig. 1c). The concentration-response curves for SNP were not different in any group (data not shown).

\section{Contractile Responses}

PHE and U46619 produced concentration-dependent contraction responses in isolated femoral rings in all groups. In cavernosal strips, PHE and adrenergic nerve stimulation (EFS) also induced contractile responses in all groups. Neither the $\mathrm{E}_{\mathrm{MAX}}$ nor $\mathrm{pEC}_{50}$ values were modified in femoral rings (Table 3; Fig. 2a, b, respectively) or cavernosal strips (Table 3; Fig. 2c, d, respectively) in any of the groups.

\section{Protein Expression of NOS}

In the femoral artery, eNOS protein expression was significantly decreased in the h-SD group (approximately $45 \%)$ compared with the c-SD group. Exercise training (h-TR group) completely restored the expression of this protein (Fig. 3a).

In contrast, in the corpus cavernosum, we did not find any alteration in protein expression of eNOS (Fig. 3b) and nNOS (Fig. 3c) in the h-SD group compared with the c-SD group. On the other hand, eNOS protein expression was increased in the h-TR group (approximately 60\%) compared with the h-SD group (Fig. 3b), with no differences in nNOS protein expression (Fig. 3c).

No change was found in any protein expression in healthy animals in the c-TR group compared with the c-SD group (Fig. 3) in the femoral artery and corpus cavernosum.

\section{NO Production}

$\mathrm{NO}$ production evoked by $\mathrm{ACh}(30 \mu \mathrm{M}$ in the femoral artery and $100 \mu \mathrm{M}$ in the corpus cavernosum) was completely abrogated in the h-SD group compared with the c-SD group, whereas exercise training fully restored the NO production in both the femoral artery (Fig. 4a) and the corpus cavernosum (Fig. 4b) in the h-TR group. Under basal conditions, $\mathrm{NO}$ production was not modified in either preparation in any group (data not shown). 

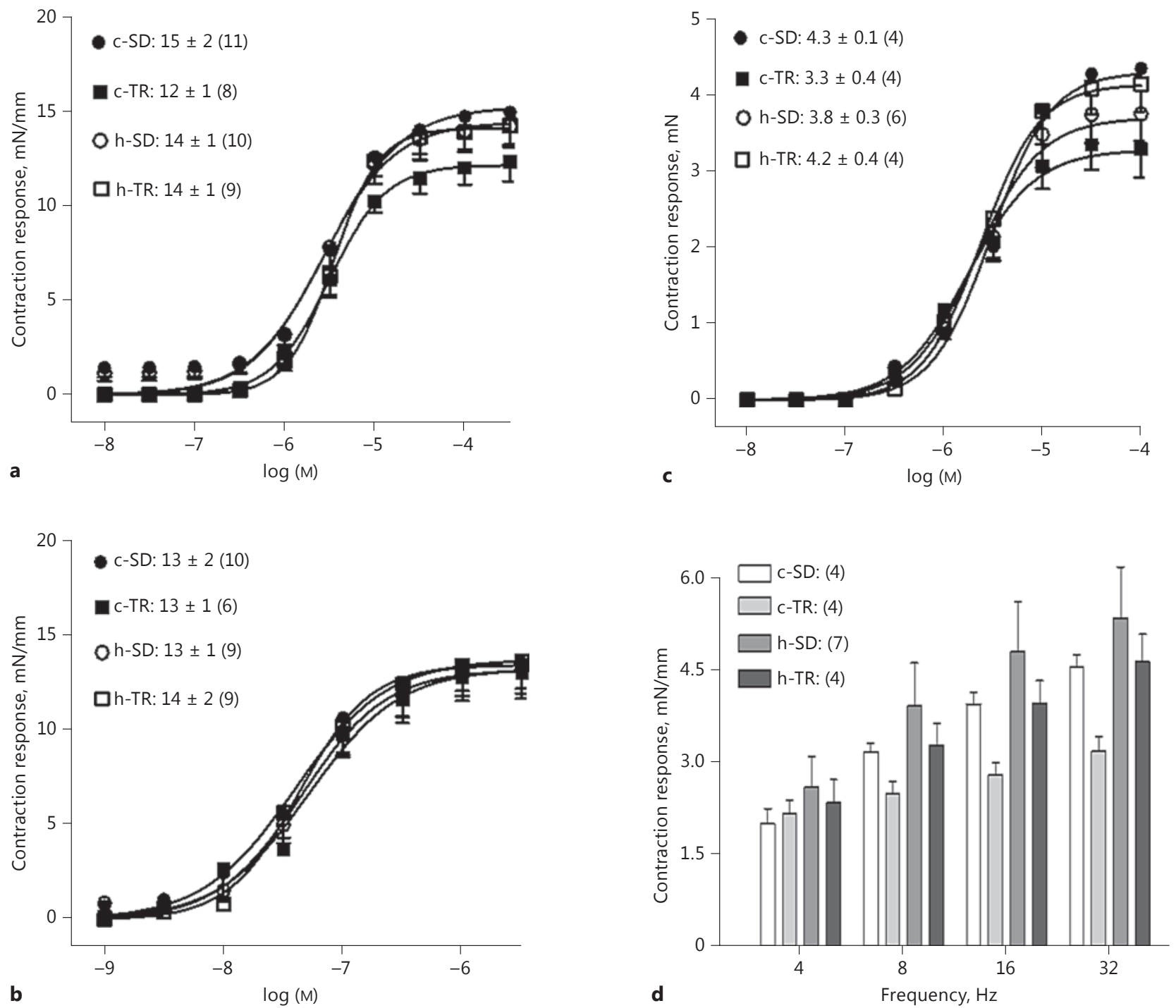

Fig. 2. Concentration-response curves to phenylephrine (PHE; a, c) and the thromboxane analog U46619 (b) in the femoral artery (a, b) and corpus cavernosum of sedentary (c-SD) and trained control rats (c-TR), and sedentary (h-SD) and trained rats on a high-fat diet (h-TR) (c). d Corpus cavernosum contractile responses to electrical-field stimulation (EFS: 4-32 Hz). Maximal response values and means \pm SEM are shown. Numbers of animals are given in parentheses.

No change was found in NO production in healthy animals in the c-TR group compared with the c-SD group (Fig. 4) in the femoral artery and corpus cavernosum.

\section{Protein Expression of SOD Isoforms}

In the femoral artery, $\mathrm{Cu} / \mathrm{Zn}-\mathrm{SOD}$ protein expression was significantly decreased in the h-SD group (approxi- mately 40\%) compared with the c-SD group. Exercise training (h-TR) completely restored the reduction in these proteins in the h-TR group (Fig. 5a). The protein expression of Mn-SOD (Fig. 5b) and Ec-SOD (Fig. 5c) was not affected by any of the experimental protocols.

In the corpus cavernosum, we did not find any alteration in protein expression in the $\mathrm{h}-\mathrm{SD}$ group compared 
with the c-SD group (Fig. 5d-f). On the other hand, $\mathrm{Cu} /$ Zn-SOD (Fig. 5d) and Ec-SOD (Fig. 5f) protein expression was increased in the h-TR group (approximately 50 and $40 \%$, respectively) compared with the h-SD group with no changes in Mn-SOD protein expression (Fig. 5e).

No change was found in any protein expression in healthy animals in the c-TR group compared with the c-SD group (Fig. 5) in the femoral artery and corpus cavernosum.

\section{ROS Generation}

In addition, an increase in ROS in the h-SD group (approximately $25 \%$ in the femoral artery and $55 \%$ in the corpus cavernosum) compared with the c-SD group was observed. The exercise training abolished the elevated ROS generation in h-TR animals compared with h-SD animals (Fig. 6a, b).

No change was found regarding ROS generation in healthy animals in the c-TR group compared with the c-SD group (Fig. 6) in the femoral artery and corpus cavernosum.

\section{Plasma Pro- and Anti-Inflammatory Biomarkers}

No changes were observed in any group in the levels of the anti-inflammatory biomarker, adiponectin (Fig. 7a). On the other hand, circulatory levels of the pro-inflammatory cytokines leptin, TNF- $\alpha$, MCP-1, and PAI- 1 were markedly increased in the h-SD group (approximately 150, 65, 190 and 420\%; Fig. 7b-e, respectively). Exercise training restored these alterations in the $\mathrm{h}$-TR group. No changes were found in the levels of pro- and anti-inflammatory biomarkers in animals in the c-TR group compared with the c-SD group (Fig. 7).

\section{Protein Expression of Adipocytokine Receptors}

Regarding the protein expression of ObR, AdipoR1, and TNFR1 in the femoral artery, we detected a decreased protein expression only of ObR in the h-SD group (approximately $43 \%$ ) compared with the c-SD group. In the

Fig. 3. a, b Protein expression of endothelial nitric oxide synthase (eNOS) in the femoral artery (a) and corpus cavernosum of rats (b). c Protein expression of neuronal nitric oxide synthase (nNOS) in the corpus cavernosum of sedentary (c-SD) and trained control rats (c-TR), and sedentary (h-SD) and trained rats on a high-fat diet (h-TR). AU, arbitrary units relative to c-SD. Bottom panels are representative Western blots and top panels show quantitative analyses. Means \pm SEM. The number of animals per group is indicated in the figure. Two-way ANOVA: ${ }^{* *} p<0.01$ vs. c-SD; ${ }^{+} p<$ 0.05 vs. h-SD.

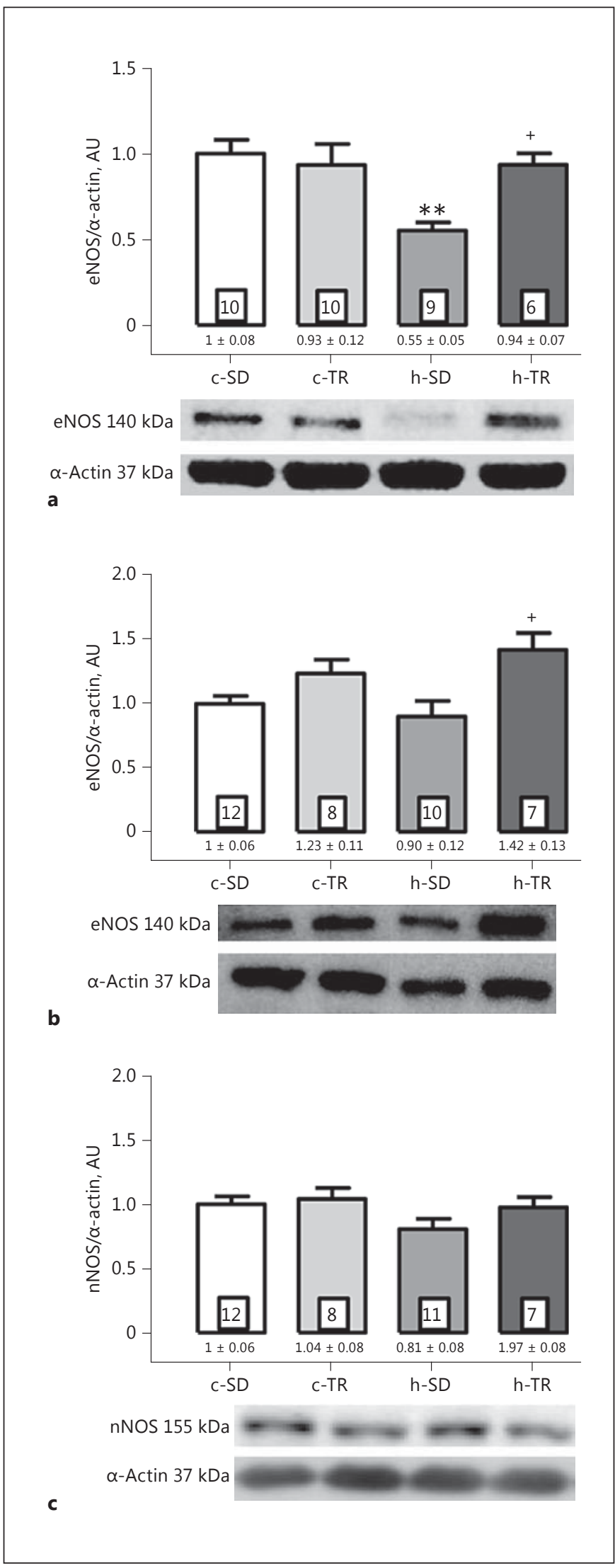

Sponton/Silva/Araujo/Valgas da Silva/ de Moraes/Antunes/Zanesco/Delbin 


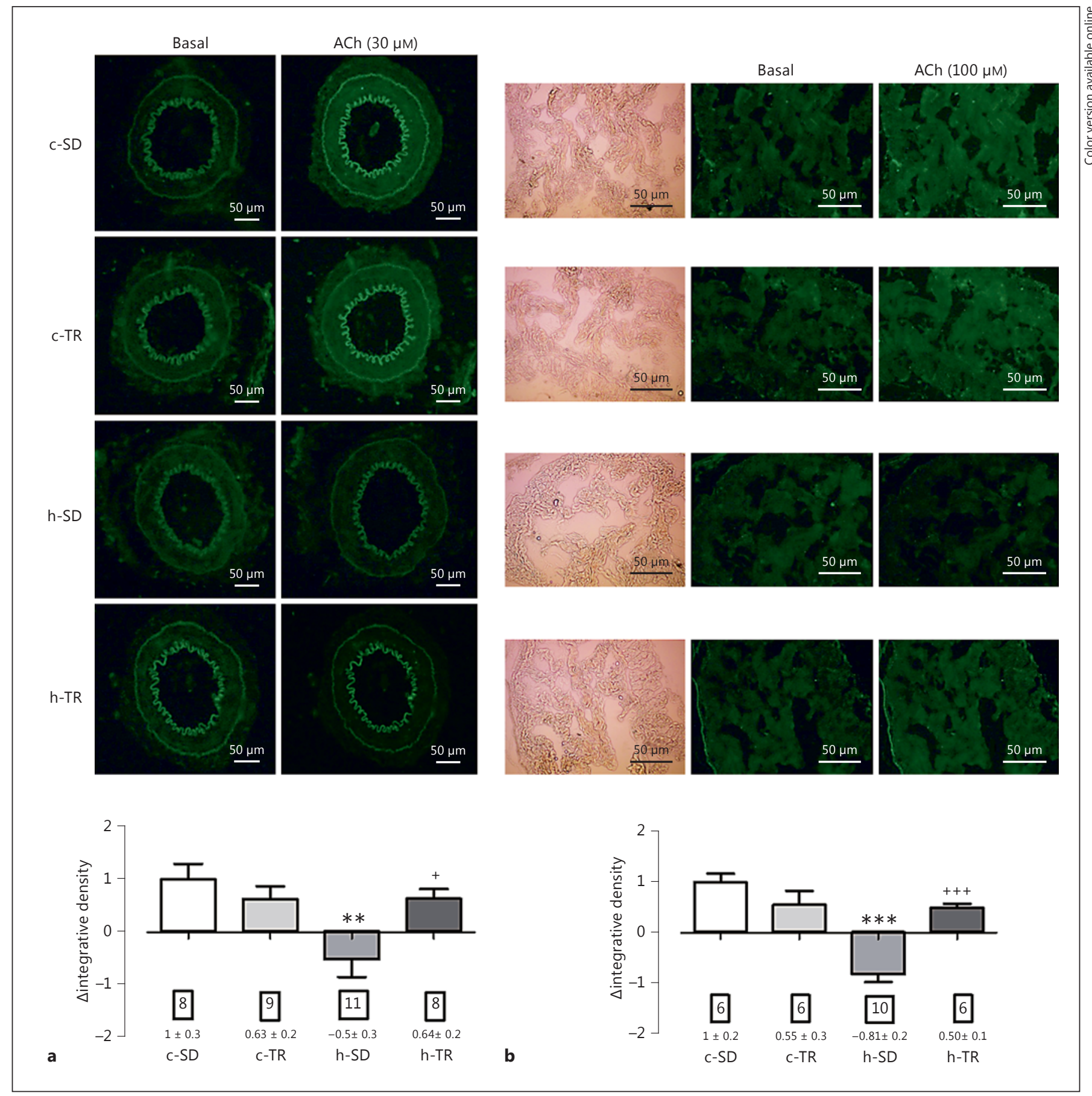

Fig. 4. Nitric oxide production in the femoral artery and corpus cavernosum. Representative fluorographs of DAF-2-treated sections without (Basal) or with acetylcholine (ACh, 30 or $100 \mu \mathrm{M})$ stimulation of the femoral artery $(\mathbf{a} ; \times 20)$ and corpus cavernosum $(\mathbf{b} ; \times 10)$ from sedentary $(\mathrm{c}-\mathrm{SD})$ and trained control rats $(\mathrm{c}-\mathrm{TR})$, and sedentary (h-SD) and trained rats on a high-fat diet (h-TR) (upper panels). Quantitative analysis of NO production measured by DAF-2 ( $\triangle \mathrm{ACh}$ integrative density - basal integrative density) relative to $\mathrm{c}$-SD in transverse sections of the femoral artery $(\mathbf{a})$ and corpus cavernosum (b; the images with [right] and without [left] fluorescein filter) (lower panel). Means \pm SEM. The number of animals per group is indicated in the figure. Two-way ANOVA: ${ }^{* *} p<0.01,{ }^{* * *} p<0.001$ vs. $c-S D ;{ }^{+} p<0.05,{ }^{++} p<0.001$ vs. h-SD. 

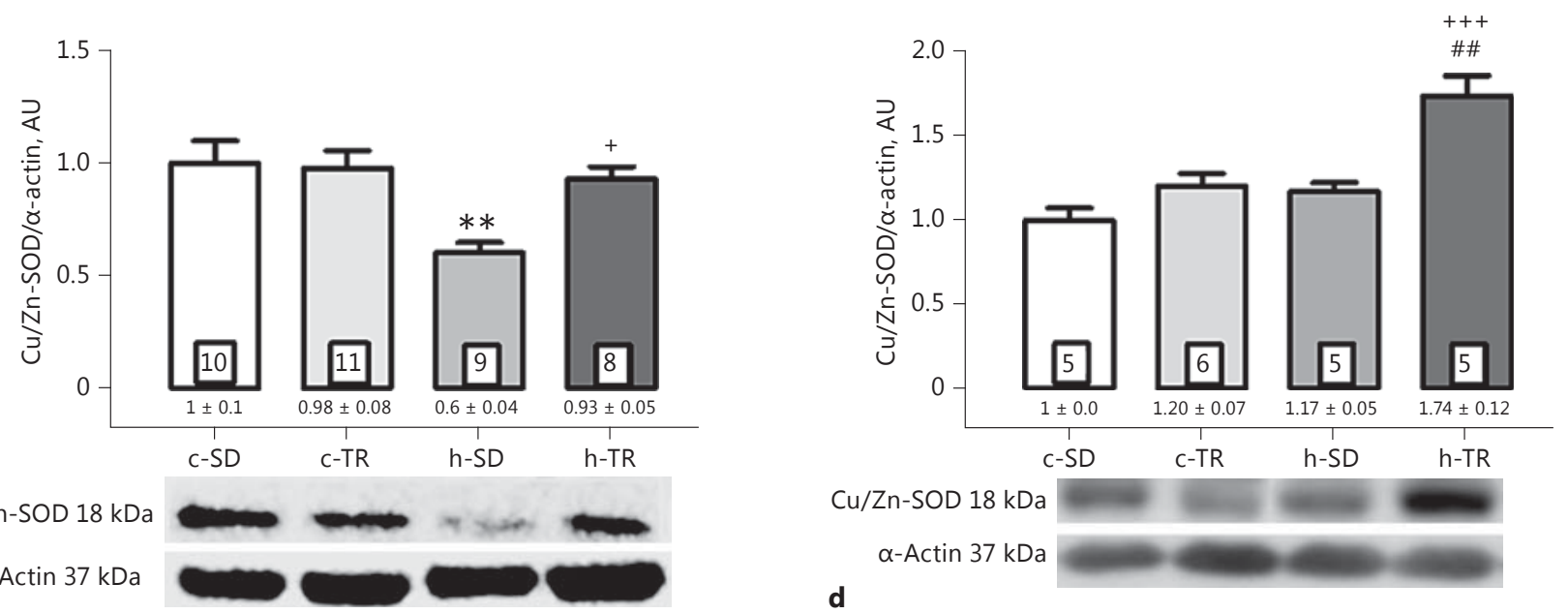

$\mathrm{Cu} / \mathrm{Zn}-\mathrm{SOD} 18 \mathrm{kDa}$

$\alpha$-Actin $37 \mathrm{kDa}$

d
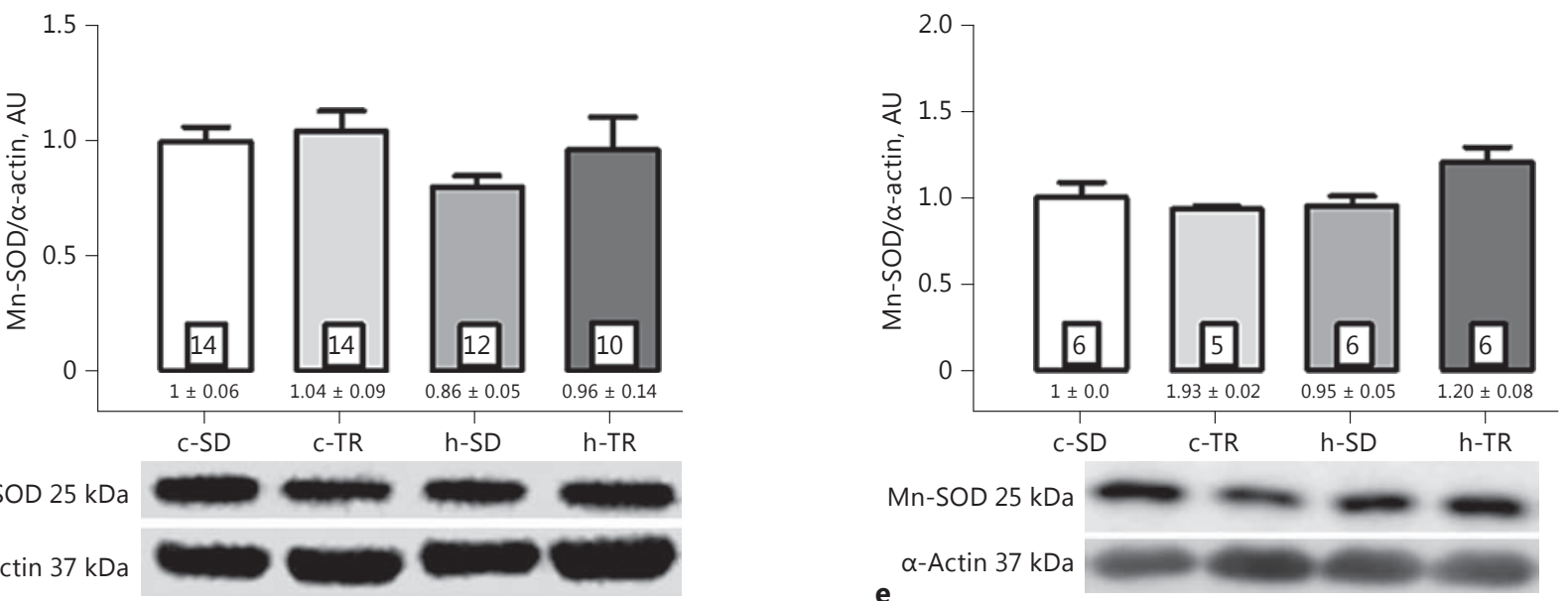

$\mathrm{Mn}-\mathrm{SOD} 25 \mathrm{kDa}$

$\alpha$-Actin $37 \mathrm{kDa}$

e
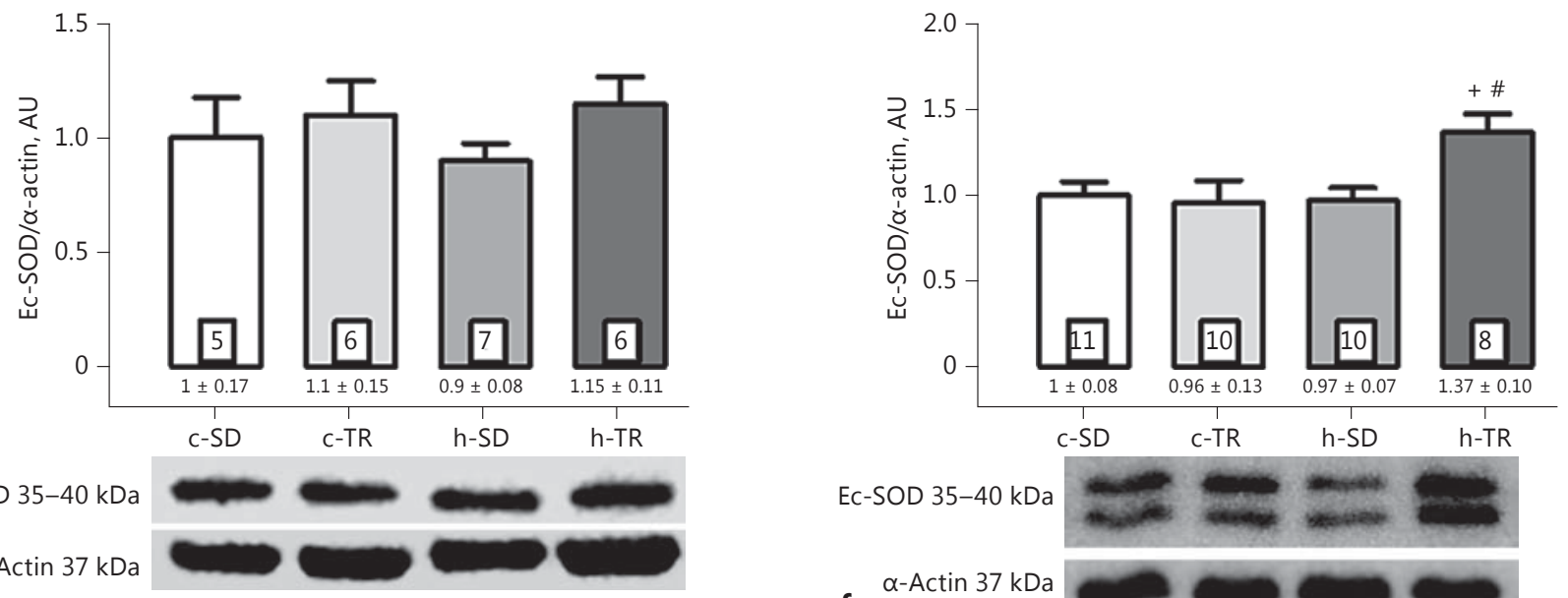

Ec-SOD $35-40 \mathrm{kDa}$

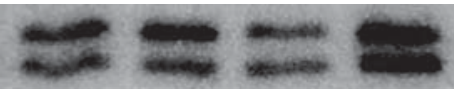

$\alpha-\operatorname{Actin} 37 \mathrm{kDa}$

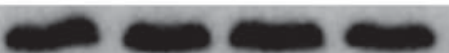

(For legend see next page.) 
h-TR group, expression of this protein was normalized (Fig. 8a).

In the corpus cavernosum, we did not find any alteration in protein expression of ObR (Fig. 8d) or TNFR1 (Fig. 8e) in the h-SD group compared with the c-SD group. The protein expression of AdipoR1 was not detected in any group.

No changes were found in any protein expression in healthy animals in the c-TR group as compared with the c-SD group (Fig. 8) in the femoral artery and corpus cavernosum.

\section{Discussion}

The main findings of this study were that a high-fat diet promotes (1) impairment in the relaxation responses to EFS and endothelium-dependent agonists with a reduced NO production and increased ROS generation in both the corpus cavernosum and femoral artery and (2) hyperleptinemia associated with downregulation of femoral artery ObR expression. Aerobic exercise training in rats on a high-fat diet promotes (1) improvement in relaxation responses to EFS and ACh in both the corpus cavernosum and femoral artery with upregulation of eNOS protein expression and a balance between NO and ROS generation and (2) reduced circulating concentrations of leptin and normalization of ObR protein expression in the femoral artery.

\section{Effects of High-Fat Diet}

As expected, in rats on a high-fat diet, we observed a significant increase in body weight and epidydimal fat pad that was accompanied by insulin resistance and increased levels of insulin, triglycerides, leptin, TNF- $\alpha$, MCP-1, and PAI-1, showing the efficacy of the diet employed in this study in causing metabolic and endocrine alterations. A decrease in relaxation responses to EFS and

Fig. 5. Protein expression of cytosolic $\mathrm{Cu} / \mathrm{Zn}$-superoxide dismutase $(\mathrm{Cu} / \mathrm{Zn}-\mathrm{SOD}$; a, d), mitochondrial Mn-superoxide dismutase (Mn-SOD; b, e), and extracellular superoxide dismutase $($ Ec-SOD; $\mathbf{c}, \mathbf{f})$ in the femoral artery $(\mathbf{a}-\mathbf{c})$ and corpus cavernosum (b-f) of sedentary (c-SD) and trained control rats (c-TR), and sedentary (h-SD) and trained rats on a high-fat diet (h-TR). Bottom panels are representative Western blots and top panels show quantitative analyses. AU, arbitrary units relative to c-SD. Means \pm SEM. The number of animals per group is indicated in the figure. Two-way ANOVA: ${ }^{* *} p<0.01$ vs. $\mathrm{c}-\mathrm{SD} ;{ }^{+} p<0.05,{ }^{+++} p<0.001$ vs. h-SD; ${ }^{\#} p<0.05,{ }^{\# \#} p<0.01$ vs. c-TR.

Aerobic Exercise Training and Vascular

Function in High-Fat-Fed Rats
ACh was observed in the corpus cavernosum and femoral artery, respectively, in the h-SD group with an impairment in the eNOS/NO signaling pathway measured by $\mathrm{NO}$ production in both tissue types. An imbalance in the redox state was also detected, possibly caused by chronic proinflammatory responses in diet-induced obesity. Accordingly, previous studies have demonstrated an impairment in relaxation responses in penile arteries [17, 33-35], aorta [36, 37], and mesenteric [38, 39], femoral $[40,41]$, and coronary arteries [33] in experimental models of obesity that were associated with diminished NO release.

To examine the effects of proinflammatory mediators on vascular diseases, we measured the protein expression of ObR in the corpus cavernosum and femoral artery given that the leptin receptor (short and long forms of ObR) has been identified in endothelial cells [22,23]. Downregulation of $\mathrm{Ob}$ protein expression was found in the femoral artery of obese animals associated with hyperleptinemia. Indeed, previous studies have shown that a long-term high-fat diet induces desensitization of $\mathrm{Ob}$ in the central nervous system [42] and coronary arterioles [43]. In the central nervous system, the role of the downregulation of ObR or its desensitization is well described as interrupting the leptin signaling pathway and changing body weight homeostasis [44]. However, the effect of leptin or its receptor on the cardiovascular system is unclear. Leptin increases sympathetic nervous system activity with increases in blood pressure and heart rate, whereas its action on vascular tissue promotes NO release causing endothelium-dependent dilatation [45]. In our experimental model, it seems that hyperleptinemia induced by a high-fat diet had a harmful effect on femoral vasodilatation responses. Intriguingly, no changes were seen in ObR protein expression in the isolated corpus cavernosum from obese animals. The reason for that could be the density of ObR present in this preparation or its functional significance in a tissue with rich nitrergic and cholinergic innervation where a great amount of NO is released from nitrergic fibers or stimulated by muscarinic receptors in penile endothelial cells [46].

We also investigated the relation between TNF- $\alpha$ levels and the protein expression of its receptor in the femoral artery and corpus cavernosum. The TNF- $\alpha$ signaling pathway is complex and not fully understood. In vascular tissue, eNOS protein expression and NO bioavailability are reduced in the presence of TNF- $\alpha[25,47]$. Interestingly, most studies investigated the concentrations of TNF- $\alpha$ but did not measure the expression of its receptor. 


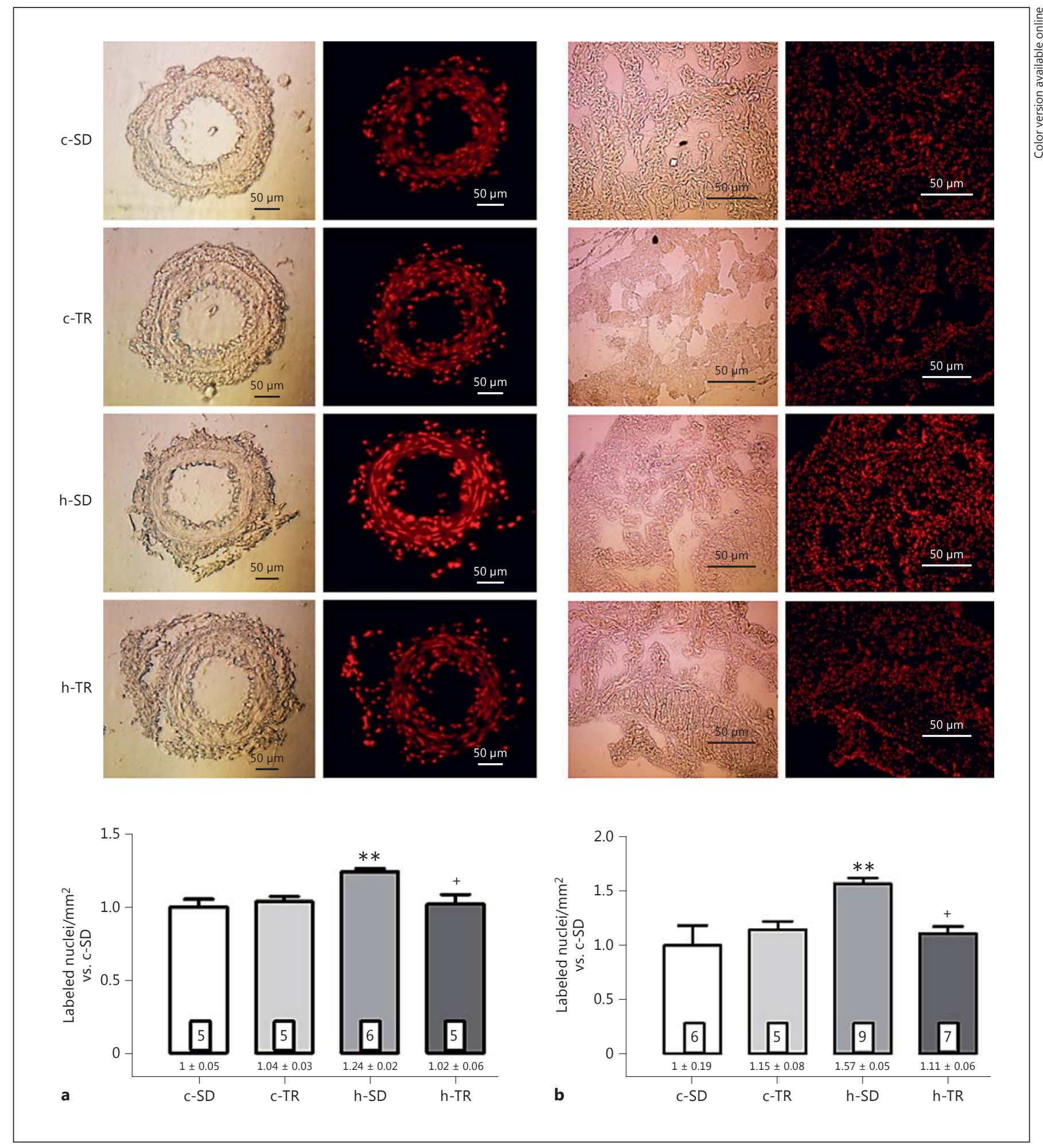

Fig. 6. Reactive oxygen species generation in the femoral artery and corpus cavernosum. Representative fluorographs (upper panels) and quantitative analyses (lower panels) of the ethidium-bromide-positive nuclei in transverse sections of the femoral artery (a; $\times 20)$ and corpus cavernosum $(\mathbf{b} ; \times 10)$ from sedentary $(c-S D)$ and trained control rats (c-TR), and sedentary (h-SD) and trained rats on a high-fat diet (h-TR) (images with [right] and without [left] rhodamine filter). Means \pm SEM. The number of animals per group is indicated in the figure. Two-way ANOVA: ${ }^{* *} p<0.01$ vs. c-SD; ${ }^{+} p<0.05$ vs. h-SD.
44

J Vasc Res 2017;54:33-50 DOI: $10.1159 / 000457800$
Sponton/Silva/Araujo/Valgas da Silva/ de Moraes/Antunes/Zanesco/Delbin 

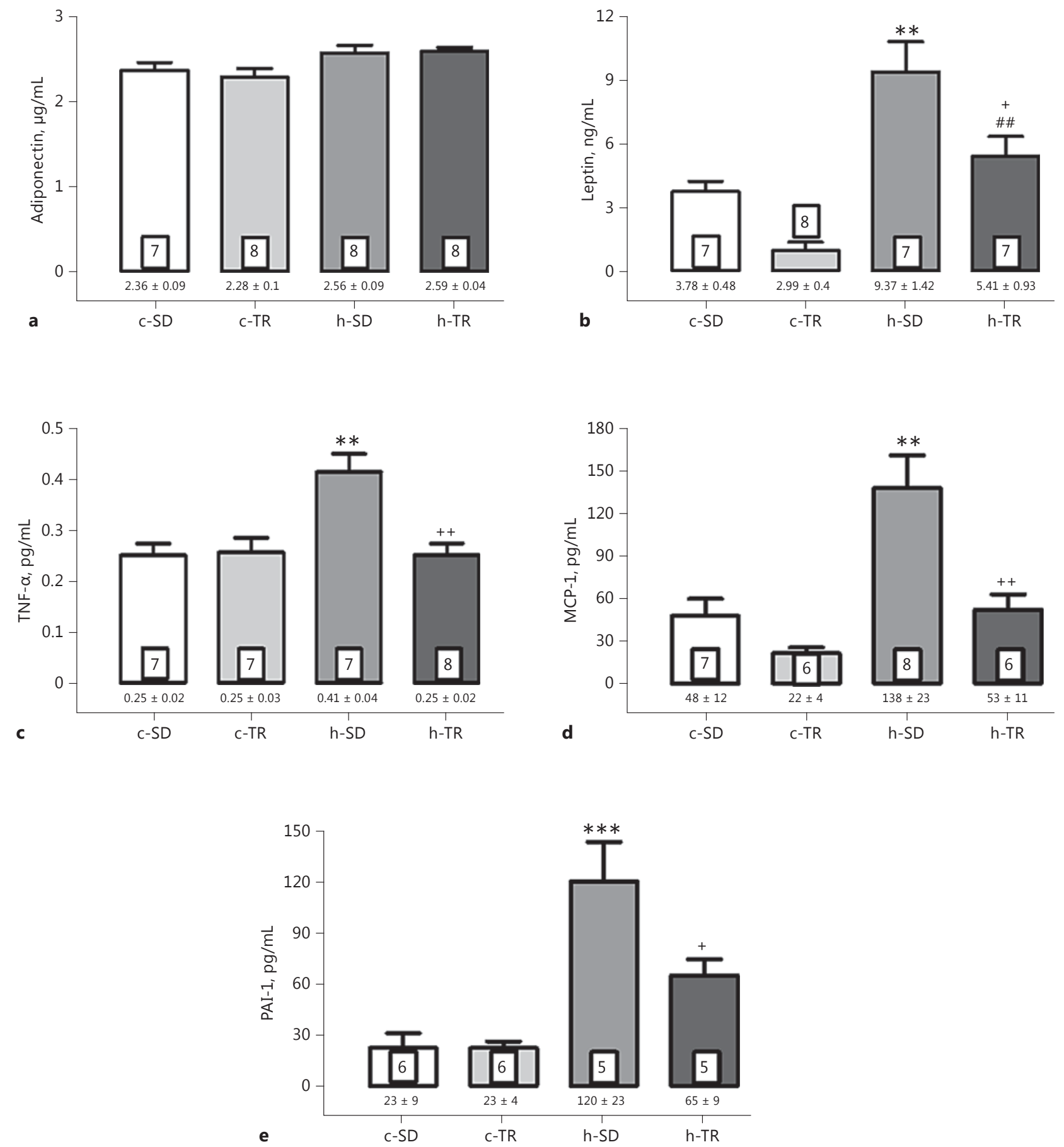

Fig. 7. Plasma levels of adiponectin (a), leptin (b), TNF-a (c), MCP-1 (d), and PAI-1 (e) in rats from sedentary (c-SD) and trained control rats (c-TR), and sedentary (h-SD) and trained rats on a high-fat diet (h-TR). Means \pm SEM. The number of animals per group is indicated in the figure. Two-way ANOVA: ${ }^{* *} p<0.01$, ${ }^{* * *} p<0.001$ vs. $\mathrm{c}-\mathrm{SD} ;{ }^{+} p<0.05,{ }^{++} p<0.01$ vs. h-SD; ${ }^{\#+} p<0.01$ vs. c-TR. 


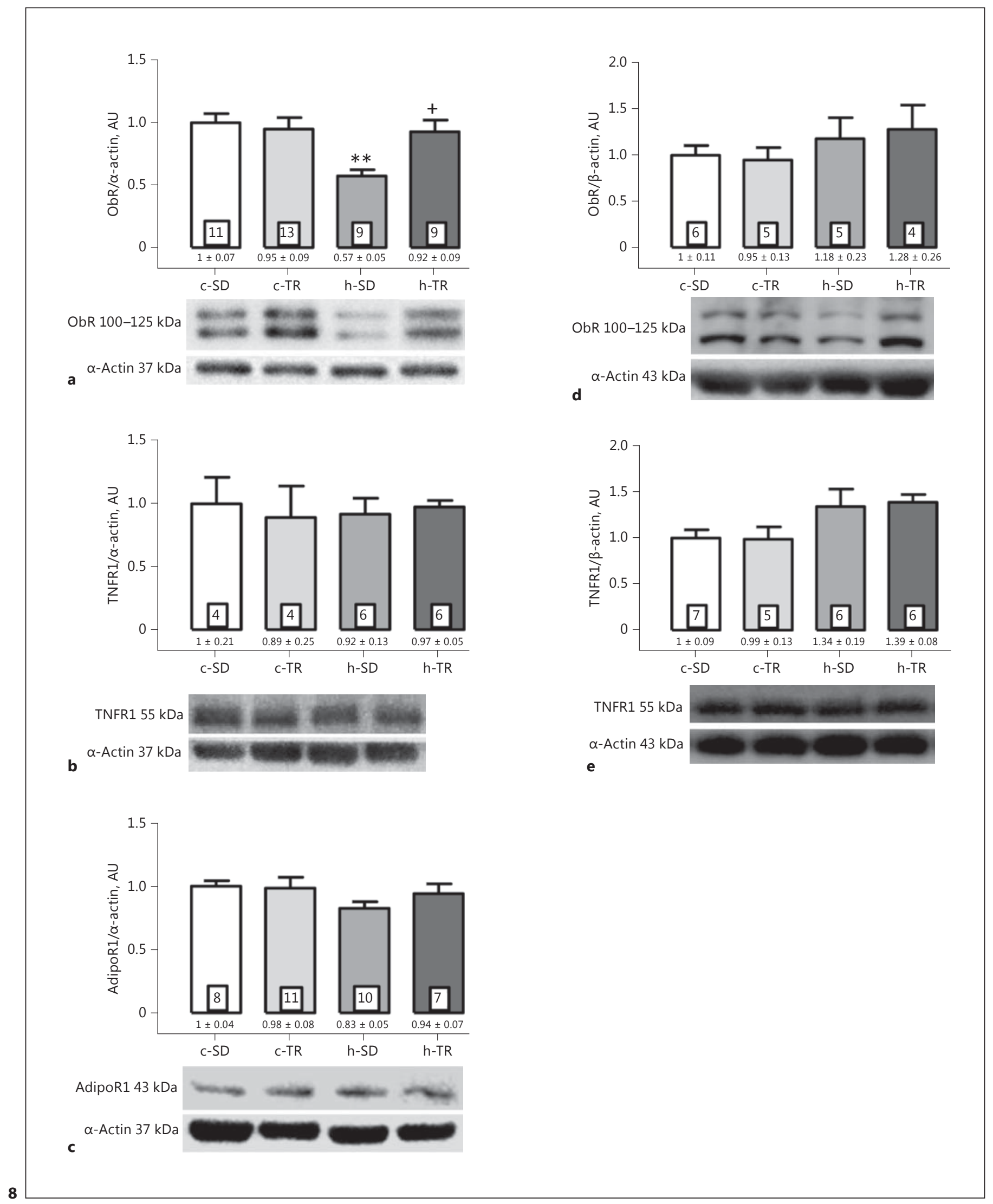

(For legend see next page.) 
In the present study, circulating TNF- $\alpha$ levels were markedly increased, but the protein expression of TNFR1 was not altered in either the corpus cavernosum or femoral artery. These findings suggest that changes in TNFR1 density are not required to induce vascular dysfunction in this model.

Adiponectin exerts vasculoprotective effects through multiple pathways that include increased $\mathrm{NO}$ production and/or its bioavailability by enhanced eNOS activity or suppression of superoxide generation $[48,49]$. More recently, the involvement of adiponectin in the regulation of TNF- $\alpha$, affecting coronary and aortic endothelium functions, has been demonstrated [50]. Previous studies showed that the concentration of adiponectin was decreased in rats on a high-fat diet [51-54], and it has been reported that plasma adiponectin levels are negatively correlated with body fat mass in humans [55]. In contrast, we failed to detect any changes in plasma adiponectin concentrations in the h-SD group or in its receptor in the femoral artery (AdipoR1). Moreover, AdipoR1 was not detected in the rat corpus cavernosum. Accordingly, a previous study found no changes in adiponectin levels in rats on a high-fat diet for 10 weeks [56]. In addition, previous studies have shown that leptin is more responsive to dietary intervention than adiponectin $[56,57]$. Therefore, plasma adiponectin remains controversial as a biomarker of cardiovascular disease in humans, and further research is necessary [58].

\section{Aerobic Exercise Training}

It is well established that aerobic exercise training promotes beneficial health effects on the cardiovascular system, improves health, and delays age-associated frailty in humans and laboratory animals [59-61]. Indeed, physical inactivity is the largest risk factor for the development of obesity [62], and the cellular mechanisms by which exercise training regulates body weight are mainly related to an increase in energy expenditure, sympathetic activity, and increments in the $\beta$-oxidation rate in mitochondria $[63,64]$.

Fig. 8. Protein expressions of leptin (ObR; a, d) and TNF-a receptors (TNFR1; b, e) in the femoral artery $(\mathbf{a}-\mathbf{c})$ and corpus cavernosum $(\mathbf{d}, \mathbf{e})$ of sedentary (c-SD) and trained control rats (c-TR), and sedentary (h-SD) and trained rats on a high-fat diet (h-TR). c Adiponectin (AdipoR1) receptor in the femoral artery of rats. Bottom panels are representative Western blots and top panels show quantitative analyses. AU, arbitrary units relative to c-SD. Means \pm SEM. The number of animals per group is indicated in the figure. Two-way ANOVA: ${ }^{* *} p<0.01$ vs. c-SD; ${ }^{+} p<0.05$ vs. h-SD.

Aerobic Exercise Training and Vascular Function in High-Fat-Fed Rats
The reduction in white adipose tissue is one of the key reasons for attenuation of the dysregulation of adipokine levels and adipokine expression induced by exercise training [65]. The increased blood flow to white adipose tissue produced by exercise training could also contribute to a decrease in inflammatory changes induced by hypoxia in obesity [66]. Exercise training is also considered an important nonpharmacological tool in the management of metabolic disorders, including the control of blood glucose, triglyceride levels, and insulin resistance [67-69]. We demonstrated that exercise training was effective in reducing body weight gain, epididymal fat pad, and blood glucose, insulin and triglyceride levels.

In agreement with previous studies [33, 38, 41, 70], our findings clearly show that exercise training improved the relaxation responses to $\mathrm{ACh}$ in the femoral artery from exercised rats on a high-fat diet in association with an upregulation of eNOS and $\mathrm{Cu} / \mathrm{Zn}$-SOD protein expression, increasing $\mathrm{NO}$ production and/or its bioavailability to this vascular tissue. In addition, exercise training was effective in reducing ROS generation, exacerbating this beneficial effect. The main mechanism is believed to be the shear stress induced by increased blood flow in response to exercise training. Indeed, physical exercise is a powerful stimulus to promote vascular shear stress activating mechanosensors present in endothelial cells. These mechanosensors are coupled to complex biochemical signaling pathways, such as Ras/MEK/ERK, c-Src, G proteins, ion channels, VE-cadherin, and PI3K/Akt, which in turn regulate the NO/cGMP pathway [71].

In the corpus cavernosum, the nonadrenergic, noncholinergic nitrergic nerves play a pivotal role in the neural mechanisms involved in penile erection through the stimulation of nNOS activity and release of NO, and eNOS also contributes to penile erection through NO production by endothelial cells in the sinusoidal spaces and arteries [72, 73]. Erectile dysfunction has been observed in obese men, and lifestyle changes have been proposed as an alternative way to ameliorate this condition, but no potential mechanisms were evaluated $[74,75]$. In the present study, aerobic exercise increased the protein expression of eNOS, Cu/Zn-SOD, and Ec-SOD and improved corpus cavernosum relaxation, suggesting that regular aerobic exercise could be an important intervention as a nonpharmacological tool of erectile dysfunction through increased production of NO and/or its bioavailability in obesity. Furthermore, the efficacy of phosphodiesterase inhibitors is approximately $67 \%$ in men with comorbidities such as obesity and dyslipidemia, and its administration is not recommended for men who are on 
vasodilator therapy [76] reinforcing the importance of physical training associated or not with phosphodiesterase inhibitors in improving the quality of life in males. Intriguingly, we found a double band for Ec-SOD protein expression in the corpus cavernosum. Accordingly, previous studies have shown a double band for Ec-SOD in different tissue types where the amount of connective tissue is high such as the lung [77] and joint cartilage [78] from mice. Given that the corpus cavernosum shows a higher amount of connective tissue than the femoral artery, the presence of a double band in this preparation, but not in the femoral artery, might be related to the different morphological characteristics of each tissue.

The contributions of exercise training towards reducing circulating adipocytokine levels may be important to other tissue responses, but the effects of ObR on vascular tissue in exercised animals are unknown since most studies examined the effect of exercise training on leptin and its receptors in adipose tissue and skeletal muscle $[79,80]$. In addition, a reduction in AdipoR1 has been reported in skeletal muscle and adipose tissue in experimental models of obesity, and exercise training was effective to prevent this alteration $[81,82]$. Our findings demonstrate that exercise training in animals on a high-fat diet is able to reduce leptin levels and upregulate its receptor in the femoral artery. These alterations possibly result in activating the NO pathway, thus enhancing the relaxation response in trained animals in this experimental model, being more meaningful in the femoral artery than in the corpus cavernosum. On the other hand, we did not detect any change in AdipoR1 in h-TR animals. In addition, aer- obic exercise reduced TNF- $\alpha$ levels with no alteration in TNFR1 protein expression. A recent study demonstrated the beneficial effect of exercise training to reduce TNFR1 protein expression in hearts from ovariectomized rats preventing cardiac apoptosis [83]. Future experiments should be developed to investigate these important pathways.

In conclusion, aerobic exercise training ameliorated the effects of inflammatory adipocytokines and restored the relaxation responses in the corpus cavernosum and femoral artery in rats on a high-fat diet. The relevance of this study is its contribution for preventing erectile dysfunction and peripheral arterial disease in obese men using nonpharmacological approaches.

\section{Acknowledgment}

This work was supported by CNPq (441514/2014-6), FAPESP (2013/26886-4), and PEMBERTON Coca-Cola Brasil (2012/2013).

\section{Statement of Ethics}

This study was approved by the Ethical Committee for Animal Research (permit No. 3203-1) at the University of Campinas (UNICAMP) established by the Brazilian College for Animal Experimentation.

\section{Disclosure Statement}

The authors have no conflicts of interest to disclose.

\section{References}

1 Billups KL: Erectile dysfunction as an early sign of cardiovascular disease. Int J Impot Res 2005;17(suppl 1):S19-S24.

2 Corona G, Rastrelli G, Filippi S, Vignozzi L, Mannucci E, Maggi M: Erectile dysfunction and central obesity: an Italian perspective. Asian J Androl 2014;16:581-591.

3 Esposito K, Giugliano F, Di Palo C, Giugliano G, Marfella R, D'Andrea F, et al: Effect of lifestyle changes on erectile dysfunction in obese men: a randomized controlled trial. JAMA 2004;291:2978-2984.

4 Claudino MA, Franco-Penteado CF, Priviero FB, Camargo EA, Teixeira SA, Muscará MN, et al: Upregulation of gp91phox subunit of NAD(P)H oxidase contributes to erectile dysfunction caused by long-term nitric oxide inhibition in rats: reversion by regular physical training. Urology 2010;75:961-967.
5 Claudino MA, Delbin MA, Franco-Penteado CF, Priviero FB, De Nucci G, Antunes E, et al: Exercise training ameliorates the impairment of endothelial and nitrergic corpus cavernosum responses in diabetic rats. Life Sci 2011; 88:272-277.

6 La Favor JD, Anderson EJ, Hickner RC, Wingard CJ: Erectile dysfunction precedes coronary artery endothelial dysfunction in rats fed a high-fat, high-sucrose, Western pattern diet. J Sex Med 2013;10:694-703.

7 La Favor JD, Anderson EJ, Dawkins JT, Hickner RC, Wingard CJ: Exercise prevents Western-diet associated erectile dysfunction and coronary artery endothelial dysfunction: response to acute apocynin and sepiapterin treatment. Am J Physiol Regul Integr Comp Physiol 2013;305:R423-R434.
8 Galal W, Van Gestel YR, Hoeks SE, Sin DD, Winkel TA, Bax JJ, et al: The obesity paradox in patients with peripheral arterial disease. Chest 2008;134:925-930

9 Roger VL, Go AS, Lloyd-Jones DM, Benjamin EJ, Berry JD, Borden WB, Bravata DM, Dai S, Ford ES, Fox CS, Fullerton HJ, Gillespie C, Hailpern SM, Heit JA, Howard VJ, Kissela BM, Kittner SJ, Lackland DT, Lichtman JH, Lisabeth LD, Makuc DM, Marcus GM, Marelli A, Matchar DB, Moy CS, Mozaffarian D, Mussolino ME, Nichol G, Paynter NP, Soliman EZ, Sorlie PD, Sotoodehnia N, Turan TN, Virani SS, Wong ND, Woo D, Turner MB; American Heart Association Statistics Committee, Stroke Statistics Subcommittee: Executive summary: heart disease and stroke statistics - 2012 update: a report from the American Heart Association. Circulation 2012;125:188-197. 
10 Brostow DP, Hirsch AT, Collins TC, Kurzer MS: The role of nutrition and body composition in peripheral arterial disease. Nat Rev Cardiol 2012;9:634-643.

11 Norgren L, Hiatt WR, Dormandy JA, Hirsch AT, Jaff MR, Diehm C, et al: The next 10 years in the management of peripheral artery disease: perspectives from the "PAD 2009" Conference. Eur J Vasc Endovasc Surg 2010;40: 375-380.

12 McDermott MM: The magnitude of the problem of peripheral arterial disease: epidemiology and clinical significance. Cleve Clin J Med 2006;73(suppl 4):S2-S7.

13 Gardner AW, Montgomery PS, Parker DE: Optimal exercise program length for patients with claudication. J Vasc Surg 2012;55:13461354.

14 Zwierska I, Walker RD, Choksy SA, et al: Upper- versus lower-limb aerobic exercise rehabilitation in patients with symptomatic peripheral arterial disease: a randomized controlled trial. J Vasc Surg 2005;42:1122-1130.

15 Molica F, Morel S, Kwak BR, Rohner-Jeanrenaud F, Steffens S: Adipokines at the crossroad between obesity and cardiovascular disease. Thromb Haemost 2015;113:553-566. Erratum in: Thromb Haemost 2015;113:909.

16 Meller SM, Stilp E, Walker CN, Mena-Hurtado C: The link between vasculogenic erectile dysfunction, coronary artery disease, and peripheral artery disease: role of metabolic factors and endovascular therapy. J Invasive Cardiol 2013;25:313-319.

17 Toque HA, da Silva FH, Calixto MC, Lintomen L, Schenka AA, Saad MJ, et al: High-fat diet associated with obesity induces impairment of mouse corpus cavernosum responses. BJU Int 2011;107:1628-1634.

18 Fornoni A, Raij L: Metabolic syndrome and endothelial dysfunction. Curr Hypertens Rep 2005;7:88-95.

19 Vila E, Salaices M: Cytokines and vascular reactivity in resistance arteries. Am J Physiol Heart Circ Physiol 2005;288:H1016-H1021.

20 Chen C, Jiang J, Lü JM, et al: Resistin decreases expression of endothelial nitric oxide synthase through oxidative stress in human coronary artery endothelial cells. Am J Physiol Heart Circ Physiol 2010;299:H193-H201.

21 Donato AJ, Henson GD, Morgan RG, et al: TNF- $\alpha$ impairs endothelial function in adipose tissue resistance arteries of mice with diet-induced obesity. Am J Physiol Heart Circ Physiol 2012;303:H672-H679.

22 Bouloumié A, Drexler HC, Lafontan M, Busse $\mathrm{R}$ : Leptin, the product of $\mathrm{Ob}$ gene, promotes angiogenesis. Circ Res 1998;83:1059-1066.

23 Sierra-Honigmann MR, Nath AK, Murakami C, García-Cardeña G, Papapetropoulos A, Sessa WC, et al: Biological action of leptin as an angiogenic factor. Science 1998;281:1683-1686.

24 Rajan S, Ye J, Bai S, Huang F, Guo YL: NF- $\kappa$ B, but not p38 MAP kinase, is required for TNFa-induced expression of cell adhesion molecules in endothelial cells. J Cell Biochem 2008; 105:477-486.
25 Kleinbongard P, Heusch G, Schulz R: TNFa in atherosclerosis, myocardial ischemia/reperfusion and heart failure. Pharmacol Ther 2010;127:295-314.

26 Aghagolzadeh P, Bachtler M, Bijarnia R, Jackson C, Smith ER, Odermatt A, Radpour R, Pasch A: Calcification of vascular smooth muscle cells is induced by secondary calciprotein particles and enhanced by tumor necrosis factor-a. Atherosclerosis 2016;251:404-414.

27 Oharomari LK, Garcia NF, Freitas EC, Jordão Júnior AA, Ovídio PP, Maia AR, et al: Exercise training and taurine supplementation reduce oxidative stress and prevent endothelium dysfunction in rats fed a highly palatable diet. Life Sci 2015;139:91-96.

28 Matthews DR, Hosker JP, Rudenski AS, Naylor BA, Treacher DF, Turner RC: Homeostasis model assessment: insulin resistance and $\beta$-cell function from fasting plasma glucose and insulin concentrations in man. Diabetologia 1985;28:412-419.

29 Mulvany MJ, Halpern W: Contractile properties of small arterial resistance vessels in spontaneously hypertensive and normotensive rats. Circ Res 1977;41:19-26.

30 Delbin MA, Davel AP, Couto GK, de Araújo GG, Rossoni LV, Antunes E, et al: Interaction between advanced glycation end products formation and vascular responses in femoral and coronary arteries from exercised diabetic rats. PLoS One 2012;7:e53318.

31 Silva FH, Lanaro C, Leiria LO, Rodrigues RL, Davel AP, Claudino MA, et al: Oxidative stress associated with middle aging leads to sympathetic hyperactivity and downregulation of soluble guanylyl cyclase in corpus cavernosum. Am J Physiol Heart Circ Physiol 2014;307:H1393-H1400.

32 Davel AP, Ceravolo GS, Wenceslau CF, Carvalho $\mathrm{MH}$, Brum PC, Rossoni LV: Increased vascular contractility and oxidative stress in $\beta_{2}$-adrenoceptor knockout mice: the role of NADPH oxidase. J Vasc Res 2012;49:342352.

33 La Favor JD, Anderson EJ, Dawkins JT, Hickner RC, Wingard CJ: Exercise prevents Western diet-associated erectile dysfunction and coronary artery endothelial dysfunction: response to acute apocynin and sepiapterin treatment. Am J Physiol Regul Integr Comp Physiol 2013;305:R423-R434.

34 Silva FH, Alexandre EC, Calmasini FB, Calixto MC, Antunes E: Treatment with metformin improves erectile dysfunction in a murine model of obesity associated with insulin resistance. Urology 2015;86:423.e1-e6.

35 Sánchez A, Contreras C, Martínez MP, Climent B, Benedito S, García-Sacristán A, et al: Role of neural NO synthase (nNOS) uncoupling in the dysfunctional nitrergic vasorelaxation of penile arteries from insulin-resistant obese Zucker rats. PLoS One 2012;7:e36027.

36 Deng G, Long Y, Yu YR, Li MR: Adiponectin directly improves endothelial dysfunction in obese rats through the AMPK-eNOS pathway. Int J Obes (Lond) 2010;34:165-171.
37 Erdei N, Tóth A, Pásztor ET, Papp Z, Edes I, Koller A, et al: High-fat diet-induced reduction in nitric oxide-dependent arteriolar dilation in rats: role of xanthine oxidase-derived superoxide anion. Am J Physiol Heart Circ Physiol 2006;29:H2107-H2115.

38 De Moraes C, Davel AP, Rossoni LV, Antunes E, Zanesco A: Exercise training improves relaxation response and SOD-1 expression in aortic and mesenteric rings from high caloric diet-fed rats. BMC Physiol 2008;8:12.

39 Naderali EK, Pickavance LC, Wilding JP, Williams G: Diet-induced endothelial dysfunction in the rat is independent of the degree of increase in total body weight. Clin Sci (Lond) 2001;100:635-641.

40 Bender SB, Laughlin MH: Modulation of endothelial cell phenotype by physical activity: impact on obesity-related endothelial dysfunction. Am J Physiol Heart Circ Physiol 2015;309:H1-H8.

41 Jen CJ, Chan HP, Chen HI: Chronic exercise improves endothelial calcium signaling and vasodilatation in hypercholesterolemic rabbit femoral artery. Arterioscler Thromb Vasc Biol 2002;22:1219-1224.

42 Lin S, Thomas TC, Storlien LH, Huang XF: Development of high fat diet-induced obesity and leptin resistance in C57Bl/6J mice. Int J Obes Relat Metab Disord 2000;24:639-646.

43 Park Y, Booth FW, Lee S, Laye MJ, Zhang C: Physical activity opposes coronary vascular dysfunction induced during high fat feeding in mice. J Physiol 2012;590:4255-4268.

44 Heshka JT, Jones PJ: A role for dietary fat in leptin receptor, OB-Rb, function. Life Sci 2001;69:987-1003.

45 Haynes WG: Interaction between leptin and sympathetic nervous system in hypertension. Curr Hypertens Rep 2000;2:311-318.

46 Priviero FB, Zemse SM, Teixeira CE, Webb RC: Oxidative stress impairs vasorelaxation induced by the soluble guanylyl cyclase activator BAY 41-2272 in spontaneously hypertensive rats. Am J Hypertens 2009;22:493499.

47 Neumann P, Gertzberg N, Johnson A: TNFalpha induces a decrease in eNOS promoter activity. Am J Physiol Lung Cell Mol Physiol 2004;286:L452-L459.

48 Chen H, Montagnani M, Funahashi T, Shimomura I, Quon MJ: Adiponectin stimulates production of nitric oxide in vascular endothelial cells. J Biol Chem 2003;278:4502145026.

49 Motoshima H, Wu X, Mahadev K, Goldstein BJ: Adiponectin suppresses proliferation and superoxide generation and enhances eNOS activity in endothelial cells treated with oxidized LDL. Biochem Biophys Res Commun 2004;315:264-271.

50 Zhang H, Park Y, Zhang C: Coronary and aortic endothelial function affected by feedback between adiponectin and tumor necrosis factor $\alpha$ in type 2 diabetic mice. Arterioscler Thromb Vasc Biol 2010;30:2156-2163. 
51 Miczke A, Suliburska J, Pupek-Musialik D, Ostrowska L, Jabłecka A, Krejpcio Z, et al: Effect of L-arginine supplementation on insulin resistance and serum adiponectin concentration in rats with fat diet. Int J Clin Exp Med 2015;8:10358-10366.

52 Yida Z, Imam MU, Ismail M, Ismail N, Ideris A, Abdullah MA: High fat diet-induced inflammation and oxidative stress are attenuated by $\mathrm{N}$-acetylneuraminic acid in rats. J Biomed Sci 2015;22:96.

53 Hadrich F, Mahmoudi A, Bouallagui Z, Feki I, Isoda H, Feve B, et al: Evaluation of hypocholesterolemic effect of oleuropein in cholesterol-fed rats. Chem Biol Interact 2016;252: 54-60.

54 Fiorino P, Américo ALV, Muller CR, Evangelista FS, Santos F, Leite APO, et al: Exposure to high-fat diet since post-weaning induces cardiometabolic damage in adult rats. Life Sci 2016;160:12-17.

55 Staiger H, Tschritter O, Machann J, Thamer C, Fritsche A, Maerker E, et al: Relationship of serum adiponectin and leptin concentrations with body fat distribution in humans. Obes Res 2003;11:368-372.

56 Serrano A, Pavón FJ, Suarez J, Rivera P, Vida M, Bermúdez-Silva FJ, et al: Adiponectin promoter activator NP-1 reduces body weight and hepatic steatosis in high-fat diet-fed animals. Am J Physiol Endocrinol Metab 2012; 302:E817-E830.

57 Tinkov AA, Gatiatulina ER, Popova EV, Polyakova VS, Skalnaya AA, Agletdinov EF, et al: Early high-fat feeding induces alteration of trace element content in tissues of juvenile male Wistar rats. Biol Trace Elem Res 2017; 175:367-374.

58 Woodward L, Akoumianakis I, Antoniades C: Unravelling the adiponectin paradox: novel roles of adiponectin in the regulation of cardiovascular disease. Br J Pharmacol 2016, Epub ahead of print.

59 Garcia-Valles R, Gomez-Cabrera MC, Rodriguez-Mañas L, Garcia-Garcia FJ, Diaz A, Noguera I, et al: Life-long spontaneous exercise does not prolong lifespan but improves health span in mice. Longev Healthspan 2013; 2:14.

60 Judge S, Jang YM, Smith A, Selman C, Phillips T, Speakman JR, et al: Exercise by lifelong voluntary wheel running reduces subsarcolemmal and interfibrillar mitochondrial hydrogen peroxide production in the heart. Am J Physiol Regul Integr Comp Physiol 2005; 289:R1564-R1572.
61 Kodama S, Saito K, Tanaka S, Maki M, Yachi $\mathrm{Y}$, Asumi M, et al: Cardiorespiratory fitness as a quantitative predictor of all-cause mortality and cardiovascular events in healthy men and women: a meta-analysis. JAMA 2009;301: 2024-2035.

62 Jankovic N, Geelen A, Streppel MT, de Groot LC, Kiefte-de Jong JC, Orfanos P, et al: WHO guidelines for a healthy diet and mortality from cardiovascular disease in European and American elderly: the CHANCES project. Am J Clin Nutr 2015;102:745-756.

63 Horowitz JF: Fatty acid mobilization from adipose tissue during exercise. Trends Endocrinol Metab 2003;14:386-392.

64 Thompson D, Karpe F, Lafontan M, Frayn K: Physical activity and exercise in the regulation of human adipose tissue physiology. Physiol Rev 2012;92:157-191.

65 Sakurai T, Ogasawara J, Kizaki T, Sato S, Ishibashi Y, Takahashi M, et al: The effects of exercise training on obesity-induced dysregulated expression of adipokines in white adipose tissue. Int J Endocrinol 2013;2013: 801743.

66 Hatano D, Ogasawara J, Endoh S, et al: Effect of exercise training on the density of endothelial cells in the white adipose tissue of rats. Scand J Med Sci Sports 2011;21:e115-e121.

67 Colberg SR: Physical activity, insulin action, and diabetes prevention and control. Curr Diabetes Rev 2007;3:176-184.

68 Pellizzon M, Buison A, Ordiz F Jr, Santa Ana L, Jen KL: Effects of dietary fatty acids and exercise on body-weight regulation and metabolism in rats. Obes Res 2002;10:947-955.

69 Touati S, Meziri F, Devaux S, Berthelot A, Touyz RM, Laurant P: Exercise reverses metabolic syndrome in high-fat diet-induced obese rats. Med Sci Sports Exerc 2011;43:398407.

70 Touati S, Montezano AC, Meziri F, Riva C, Touyz RM, Laurant P: Exercise training protects against atherosclerotic risk factors through vascular NADPH oxidase, extracellular signal-regulated kinase $1 / 2$ and stressactivated protein kinase/c-Jun $\mathrm{N}$-terminal kinase downregulation in obese rats. Clin Exp Pharmacol Physiol 2015;42:179-185.

71 Gielen S, Schuler G, Adams V: Cardiovascular effects of exercise training: molecular mechanisms. Circulation 2010;122:1221-1238.

72 Ignarro LJ: Nitric oxide. A novel signal transduction mechanism for transcellular communication. Hypertension 1990;16:477-483.
73 Rajfer J, Pickett S, Klein SR: Laparoscopic occlusion of testicular veins for clinical varicocele. Urology 1992;40:113-116.

74 Esposito K, Giugliano F, Ciotola M, De Sio M, D’Armiento M, Giugliano D: Obesity and sexual dysfunction, male and female. Int J Impot Res 2008;20:358-365.

75 Pagano MJ, De Fazio A, Levy A, RoyChoudhury A, Stahl PJ: Age, body mass index, and frequency of sexual activity are independent predictors of testosterone deficiency in men with erectile dysfunction. Urology 2016;90: 112-118.

76 Miner M, Gilderman L, Bailen J, Cook D, Dawson K, Stanislaus M, et al: Vardenafil in men with stable statin therapy and dyslipidemia. J Sex Med 2008;5:1455-1467.

77 Nozik-Grayck E, Suliman HB, Majka S, Albietz J, Van Rheen Z, Roush K, Stenmark KR: Lung EC-SOD overexpression attenuates hypoxic induction of Egr-1 and chronic hypoxic pulmonary vascular remodeling. Am J Physiol Lung Cell Mol Physiol 2008;295:L422L430.

78 Pate KM, Sherk VD, Carpenter RD, Weaver M, Crapo S, Gally F, et al: The beneficial effects of exercise on cartilage are lost in mice with reduced levels of ECSO in tissues. J Appl Physiol 2015;118:760-767.

79 De Queiroz KB, Guimarães JB, Coimbra CC, Rodovalho GV, Carneiro CM, Evangelista EA, et al: Endurance training increases leptin expression in the retroperitoneal adipose tissue of rats fed with a high-sugar diet. Lipids 2014;49:85-96

80 Kang S, Kim KB, Shin KO: Exercise training improves leptin sensitivity in peripheral tissue of obese rats. Biochem Biophys Res Commun 2013;435:454-459.

81 Chang SP, Chen YH, Chang WC, Liu IM, Cheng JT: Increase of adiponectin receptor gene expression by physical exercise in soleus muscle of obese Zucker rats. Eur J Appl Physiol 2006;97:189-195.

82 Farias JM, Maggi RM, Tromm CB, Silva LA, Luciano TF, Marques SO, et al: Exercise training performed simultaneously to a high-fat diet reduces the degree of insulin resistance and improves adipoR1-2/APPL1 protein levels in mice. Lipids Health Dis 2012;11:134.

83 Huang CY, Lin YY, Hsu CC, Cheng SM, Shyu WC, Ting H, Yang AL, Ho TJ, Lee SD: Antiapoptotic effect of exercise training on ovariectomized rat hearts. J Appl Physiol (1985) 2016;121:457-465. 